\title{
Autoantibodies Associated With Connective Tissue Diseases: What Meaning for Clinicians?
}

\author{
Kevin Didier', Loïs Bolko', Delphine Giusti3,4, Segolene Toquet ${ }^{5}$, Ailsa Robbins ${ }^{1}$, \\ Frank Antonicelli ${ }^{3,6 *}$ and Amelie Servettaz ${ }^{1,3}$
}

\begin{abstract}
'Department of Internal Medicine, Infectious Diseases, and Clinical Immunology, Reims Teaching Hospitals, Robert Debré Hospital, Reims, France, ${ }^{2}$ Rheumatology Department, Maison Blanche Hospital, Reims University Hospitals, Reims, France, ${ }^{3}$ Laboratory of Dermatology, Faculty of Medicine, EA7319, University of Reims Champagne-Ardenne, Reims, France, ${ }^{4}$ Laboratory of Immunology, Reims University Hospital, University of Reims Champagne-Ardenne, Reims, France, ${ }^{5}$ Department of Internal Medicine, $\mathrm{CHU}$ de Reims, Reims, France, ${ }^{6}$ Department of Biological Sciences, Immunology, UFR Odontology, University of Reims Champagne-Ardenne, Reims, France
\end{abstract}

OPEN ACCESS

Edited by:

Ralf J. Ludwig,

University of Lübeck, Germany

Reviewed by:

Kayo Masuko,

Sanno Medical Center, Japan

Maurizio Acampa,

Azienda Ospedaliera Universitaria

Senese, Italy

Cheng-De Yang,

Ruijin Hospital, China

*Correspondence:

Frank Antonicell

frank.antonicelli@univ-reims.fr

Specialty section:

This article was submitted to

Immunological Tolerance and

Regulation,

a section of the journal

Frontiers in Immunology

Received: 15 January 2018 Accepted: 02 March 2018

Published: 26 March 2018

Citation:

Didier K, Bolko L, Giusti D, Toquet S, Robbins A, Antonicelli F and Servettaz A (2018) Autoantibodies Associated With Connective Tissue Diseases: What Meaning for Clinicians?

Front. Immunol. 9:541. doi: 10.3389/fimmu.2018.00541
Connective tissue diseases (CTDs) such as systemic lupus erythematosus, systemic sclerosis, myositis, Sjögren's syndrome, and rheumatoid arthritis are systemic diseases which are often associated with a challenge in diagnosis. Autoantibodies (AAbs) can be detected in these diseases and help clinicians in their diagnosis. Actually, pathophysiology of these diseases is associated with the presence of antinuclear antibodies. In the last decades, many new antibodies were discovered, but their implication in pathogenesis of CTDs remains unclear. Furthermore, the classification of these AAbs is nowadays misused, as their targets can be localized outside of the nuclear compartment. Interestingly, in most cases, each antibody is associated with a specific phenotype in CTDs and therefore help in better defining either the disease subtypes or diseases activity and outcome. Because of recent progresses in their detection and in the comprehension of their pathogenesis implication in CTD-associated antibodies, clinicians should pay attention to the presence of these different AAbs to improve patient's management. In this review, we propose to focus on the different phenotypes and features associated with each autoantibody used in clinical practice in those CTDs.

\footnotetext{
Keywords: antibody, systemic lupus erythematosus, Sjögren's syndrome, systemic sclerosis, antisynthetase syndrome, dermatomyositis, necrotizing myopathy, rheumatoid arthritis
}

Abbreviations: $\mathrm{AAb}$, autoantibody; ACPA, anti-citrullinated protein/peptide antibody; ACR, American College of Rheumatology; ANA, antinuclear antibody; anti-dsDNA, anti-double-stranded DNA; AQP4, aquaporin 4; APL, antiphospholipid; APS, antiphospholipid syndrome; ASS, antisynthetase syndrome; $\mathrm{CCP}$, cyclic citrullinated peptide; $\mathrm{CHB}$, congenital heart block; CN1a, cytosolic 5'-nucleotidase 1A; CTD, connective tissue disease; DM, dermatomyositis; dSSc, diffuse systemic sclerosis; EULAR, European League Against Rheumatism; GAPSS, global antiphospholipid score; HMGCR, 3-hydroxy3-methylglutaryl-coenzyme A reductase; IBM, inclusion body myositis; IIF, indirect immunofluorescence; ILD, interstitial lung disease; ISSc, limited systemic sclerosis; MCTD, mixed connective tissue disease; MDA5, melanoma differentiation-associated gene 5; NM, necrotizing myopathy; NMO, neuromyelitis optica; NOR, nucleolus organizer region; NuRD, nucleosome remodeling histone deacetylase protein complex; NXP2, nuclear matrix protein 2; PAH, pulmonary arterial hypertension; PF, pulmonary fibrosis; RA, rheumatoid arthritis; RF, rheumatoid factor; SAE, small ubiquitin-like modifier activating enzyme; SLE, systemic lupus erythematosus; SLICC, Systemic Lupus International Collaborating Clinics; SRP, signal recognition particle; SS, Sjögren's syndrome; SSc, systemic sclerosis; TdP, torsade de pointes; TIF1- $\gamma$, transcription intermediary factor 1 gamma. 


\section{INTRODUCTION}

Connective tissue diseases (CTDs) are autoimmune diseases characterized by the involvement of several organs and the presence of various autoantibodies (AAbs). Their implication in the pathogenesis of these CTD remains partly unclear; nevertheless, we know that some of these AAbs are directly involved in tissue damages whereas some are just markers of disease development.

During the last decades, many improvements were made in the comprehension of CTD pathogenesis, and a lot of new AAb were described. The presence of AAb can help the clinician in his approach to search an autoimmune disease (1), as sometimes the production of specific $\mathrm{AAb}$ precedes the symptoms and the diagnosis of the CTD $(2,3)$. Indeed, in most cases, those AAbs are detected in a specific CTD, making the diagnosis easier. Actually, most studies recently published focused on the clinical impact of AAb in different CTD and found that some AAbs are clearly associated with a specific phenotype in one type of CTD, allowing the clinician to adapt the follow-up of his patient and to predict some complications. However, relationship between $\mathrm{AAb}$ presence and disease diagnosis is not always that simple, as some other AAbs can be associated with more than one disease. Furthermore, differences can exist for the same kind of CTD according to the population studied, strengthening the fact that genetical factors in CTD pathogenesis are probably more important than we actually know. A potential explanation to these variations may be related to genetic and environmental factors, which may play a key role in these diseases predisposition and outcome.

Indeed, pathogenesis of CTD seems associated with the presence of AAb. However, many new AAbs were discovered, but their implication in pathogenesis of connective tissue diseases (CTDs) remains unclear. Many of these AAbs are antinuclear antibody (ANA). Nevertheless, the classification of ANA is nowadays misused, as their targets can be localized outside of the nuclear compartment (cytoplasmic, membrane, or extracellular), even if the term ANA is still currently used in clinic.

Because of the new improvements in their detection and comprehension of their pathological implication in CTDs-associated antibodies, clinicians should pay attention to the presence of the different AAbs to improve patient's management. In this review, we propose to focus on the different phenotypes and features associated with each AAb used in clinical practice in CTD clearly defined such as systemic lupus erythematosus (SLE), Sjögren's syndrome (SS), systemic sclerosis (SSc), myositis, and rheumatoid arthritis (RA). Especially, we will highlight the usefulness of their clinical determination.

\section{AAb IN HEALTHY POPULATION AND IN NON-AUTOIMMUNE DISEASES}

Biological autoimmunity is not always pathological and can be observed in healthy people. The highlighting of ANA in the general population is common and estimated between 5.92 and $30.8 \%$ (4-13) with a lower prevalence in the Chinese population (4) and a higher prevalence in the Afro-American population (13) (Table 1). In addition, ANAs are more commonly detected in women than in men $(4-8,10-14)$, and the prevalence of such ANA increases with aging, as it reaches up to $24 \%$ in subjects older than 85 years (14). ANAs are commonly detected by indirect immunofluorescence (IIF) on HEp2 cells, a human HELAderivative cell line. Importantly, the relevance of a positive ANA test is directly linked to its titration. Thus, in a normal population, ANAs were found positive in $31.7 \%$ of individuals at $1 / 40$ serum dilution, $13.3 \%$ at $1 / 80,5.0 \%$ at $1 / 160$, and $3.3 \%$ at $1 / 320$ (15). The most accepted threshold is often the dilution $1 / 160$ for first screening dilution (15-17). In complement to IIF assay, which is a very sensitive technic and can now be automated $(18,19)$, screening fluorescence enzyme or chemiluminescence immunoassays have been proposed in the last few years as detection assays. These multiparametric immunoassays allow simultaneous testing for 13-17 of commonest pathogenic autoantibody specificities in systemic autoimmune diseases [i.e., SSA-52kD, SSA-60kD, SSB, U1RNP (RNP 70,A,C), CENP-B, Scl70, Jo1, Fibrillarin, RNA polymerase III, ribosomal proteins, PM-Scl, PCNA, Mi2 proteins, Sm, dsDNA, and chromatin]. These screening immunoassays showed relatively good concordance with IIF (75-83\%) and demonstrated similar or improved specificity and positive predictive value depending on the studies and the assays (20-24). However, due to the limited number of represented antigens in some screening assays and the better sensitivity of IIF, the American College of Rheumatology (ACR) ANA Task Force recommended that IIF should remain the gold standard for ANA testing (25).

In most healthy individuals with ANA, the antigenic target(s) remain(s) unknown with standard tests used to identify ANA

TABLE 1 | Presence of antinuclear antibody (ANA) in different populations considered as healthy people.

\begin{tabular}{|c|c|c|c|c|c|c|c|c|c|c|}
\hline Reference & Population & Number & $\begin{array}{c}\text { ANA positivity } \\
(\%)\end{array}$ & $\begin{array}{c}1 / 40 \\
\text { Nb (\%) }\end{array}$ & $\begin{array}{c}1 / 80 \\
\mathrm{Nb}(\%)\end{array}$ & $\begin{array}{c}1 / 160 \\
\mathrm{Nb}(\%)\end{array}$ & $\begin{array}{c}1 / 320 \\
\mathrm{Nb}(\%)\end{array}$ & $\begin{array}{c}1 / 640 \\
\mathrm{Nb}(\%)\end{array}$ & $\begin{array}{l}1 / 1,280 \\
\text { Nb (\%) }\end{array}$ & $\begin{array}{l}1 / 2,560 \\
\mathrm{Nb}(\%)\end{array}$ \\
\hline Wang et al. (4) & Chinese & 20,970 & 5.92 & $886(4.23)$ & $105(0.50)$ & $77(0.37)$ & $55(0.26)$ & $29(0.14)$ & $36(0.17)$ & $53(0.25)$ \\
\hline Minz et al. (5) & Indian & 36,310 & 12.3 & - & - & - & - & - & - & - \\
\hline Selmi et al. (6) & Italian & 2,690 & 18.1 & - & - & - & - & - & - & - \\
\hline Fernandez et al. (7) & Brazilian & 500 & 22.6 & $73(14.6)$ & $23(4.6)$ & $10(2.0)$ & $1(0.2)$ & - & $2(0.4)$ & $2(0.4)$ \\
\hline Peene et al. (8) & Belgian & 10,550 & 23.5 & - & - & - & - & - & - & - \\
\hline Hayashi et al. (10) & Japanese & 2,181 & 25.9 & - & - & - & - & - & - & - \\
\hline Racoubian et al. (11) & Lebanese & 10,814 & 26.4 & - & $2,162(20.0)$ & - & $400(3.7)$ & $183(1.7)$ & $119(1.1)$ & - \\
\hline Roberts-Thomson et al. (12) & Australian & 20,205 & 28.3 & - & - & - & - & - & - & - \\
\hline Wandstrat et al. (13) & Afro-American & 1,827 & 30.8 & - & - & - & - & - & - & - \\
\hline
\end{tabular}

ANA positivity was defined as the first titer seen in this table for each study. 
subtypes. Nevertheless, in a minority of cases, AAbs from healthy people recognize the same autoantigens as AAb from patients with autoimmune disease, especially anti-SSa in up to $3 \%$ and anti-DFS70 AAb (also called LEDGF for "lens epithelium-derived growth factor") $(4,10,11)$. Anti-SSa AAbs are frequently detected in the sera from patients with SLE and SS, whereas anti-DFS70 AAbs have mostly been evidenced in healthy people, but also in the sera from patients with benign and common diseases such as atopic dermatitis (26-29). In general population, anti-Ro/SSa AAbs are associated with torsade de pointes (TdP) and arrhythmia, representing a clinically silent novel risk factor for TdP development via an autoimmune-mediated electrophysiological interference with the hERG channel (30).

Antinuclear antibody and other AAbs can also be observed in association with drugs (such as hydralazine and procainamide) or in non-autoimmune diseases associated with a process of tolerance breakdown such as infectious or lymphoproliferative diseases.

\section{SYSTEMIC LUPUS ERYTHEMATOSUS- ASSOCIATED AAb}

Systemic lupus erythematosus is a CTD with a great variability in its clinical presentation and its prognosis. Two main classification criteria are available, based on the presence of both clinical and immunological parameters [1997 ACR classification criteria and Systemic Lupus International Collaborating Clinics (SLICC) classification criteria $(31,32)]$. The different AAbs associated with SLE and their main features are recapitulated in Table 2.

\section{ANA in SLE}

Antinuclear antibody is one of the immunological criteria present in the two SLE classifications criteria as an ANA titer detected by IIF on HEP 2 cells $>1 / 160$ is observed in nearly all SLE patients [between 94 and 100\% (33-35)]. The quantity of ANA progressively increases during the 3-5 years preceding SLE clinical expression and diagnosis (2). Consequently, ANA testing represents an essential screening tool because their negativity (titer less than 1/160) makes the diagnosis of SLE extremely unlikely (36). By contrast, their presence, even at higher titer is not SLE-specific as ANA can be produced in a lot of other circumstances such as other CTD, hematologic and hepatic diseases, virus infections, drugs uptake, and in healthy people as previously mentioned. In case of positivity, ANA antigen target(s) must be determined by additional tests with nuclear autoantigens.

\section{Clinical Usefulness of ANA Testing}

D In case of SLE suspicion given clinical symptoms

$\checkmark$ Importantly, ANAs are useless in SLE follow-up as they remain positive whatever disease activity.

\section{Antigen Targets of ANA in SLE Anti-Double-Stranded DNA (Anti-dsDNA) AAb}

Anti-double-stranded DNA AAbs are present in 43-92\% of cases (37-39) with a specificity between 89 and $99 \%$ but with variable clinical sensitivities from 8 to $54 \%(40-46)$. The methods used for anti-dsDNA AAb detection are numerous, which explains the variability observed in terms of sensitivity. Anti-dsDNA AAbs are quite well identified by nuclear homogeneous IFI pattern (47), but their presence may also be evaluated by quantitative assays such as Farr radioimmunoassay (45), chemiluminescence immunoassay $(42,43)$, ELISA (46), and fluoro-enzyme immunoassay or by qualitative assays such as immunofluorescence test on Crithidia luciliae (CLIFT) $(44,46)$. For each method, performances will vary according to the manufacturer and the source of the dsDNA (synthetic or purified ds DNA from human or calf origin). Globally, ELISA methods to detect anti-dsDNA antibodies are highly sensitive, but are less specific for the diagnosis of SLE than the immunofluorescence test on CLIFT and the Farr assay as they also detect low-avidity antibodies (48).

Anti-double-stranded DNA AAb positivity is one criteria present in both ACR and SLICC classifications (49). As for the majority of AAb, the specificity of anti-dsDNA AAb in SLE is not of $100 \%$ [specificity between 96 and $99 \%$ according to the type of test and the published series $(40,41)]$. Indeed, they can also be evidenced in the setting of infection, elevation of $C$ reactive protein and in healthy individuals (50). In SLE, the serum level of this AAb is generally correlated with disease activity (51). Moreover, high level of such $\mathrm{AAb}$ and their association with anti-Sm antibodies (defined below) are associated with kidney involvement in patients with SLE $(52,53)$.

TABLE 2 | AAb associated with systemic lupus erythematosus (SLE).

\begin{tabular}{|c|c|c|c|c|}
\hline AAb & Prevalence & Sensitivity & Specificity & Clinical features \\
\hline Anti-dsDNA & $43-92 \%(37-39)$ & $8-54 \%(40-46)$ & 89-99\% (40-46) & Correlation with disease activity \\
\hline Anti-nucleosome & $59.8-61.9 \%(53-57)$ & $52-61 \%(53-57)$ & $87.5-95.7 \%(53-57)$ & Correlation with disease activity \\
\hline Anti-Sm & $15-55.5 \%(37-39,61)$ & $10-55 \%(62)$ & $98-100 \%(62)$ & $\begin{array}{l}\text { Most specific antibody in SLE often } \\
\text { associated with anti-RNP AAb }\end{array}$ \\
\hline Anti-histone & $\begin{array}{l}50-81 \% \\
>90 \% \text { in induced SLE }(37,71,72)\end{array}$ & - & - & Drug-induced SLE \\
\hline Anti-C1q & $4-60 \%(90-93)$ & $28 \%(94-97)$ & $92 \%(94-97)$ & Associated with glomerulonephritis \\
\hline Anti-ribosomal P & $12-60 \%(37,103,104)$ & $36 \%(103,104,109)$ & $97-100 \%(103,104,109)$ & Neuropsychiatric manifestations \\
\hline Anti-Ro/SSa & $36-64 \%(37,38,61,75,76)$ & - & - & $\begin{array}{l}\text { Skin involvement+++ } \\
\mathrm{CHB}\end{array}$ \\
\hline Anti-La/SSb & 8-33.6\% (37, 38, 61, 75, 76) & $25.7 \%(85)$ & $96.7 \%(85)$ & $\begin{array}{l}\text { Skin involvement+++ } \\
\mathrm{CHB} \text { (less than anti-Ro AAb) }\end{array}$ \\
\hline Anti-RNP & $23.3-49 \%(37-39)$ & 8-69\% (62) & $25-82 \%(62)$ & - \\
\hline
\end{tabular}

$C H B$, congenital heart block; anti-dsDNA, anti-double-stranded DNA; AAb, autoantibody. 


\section{Clinical Usefulness of Anti-dsDNA AAb Testing}

$>$ In case of SLE suspicion and ANA > 1/160

$\checkmark$ In the follow-up of SLE patients when positive at time of diagnosis (the same test in the same laboratory should always be used in this setting).

\section{Anti-Nucleosome AAb}

The nucleosome is a basic unit of DNA packaging, implicated in the formation of repeating units of chromatin. The anti-nucleosome AAbs are detected in 59.8 and $61.9 \%$ of SLE patients' sera with a sensitivity between 52 and $61 \%$ (the highest sensitivity in SLE) and a specificity between 87.5 and $95.7 \%$ (54-57). Although, presenting the same nuclear homogenous pattern on Hep2 cells (47), they can be present in the absence of anti-dsDNA AAb and consequently may be helpful for clinicians at diagnosis. In SLE murine models, serum antinucleosome AAbs are produced before anti-dsDNA AAb (58). Consequently, the detection of these AAbs may be helpful to establish diagnosis. It is noteworthy that the level of antinucleosome AAb (especially IgG3 subtype) is correlated with SLE activity (59). The simultaneous presence of anti-dsDNA, anti-nucleosome, and anti-histone (defined below) AAb has been shown to be associated with severe kidney involvement (54, 60). However, such AAbs have also been detected in patients with mixed connective tissue disease (MCTD) and SSc (56).

\section{Clinical Usefulness of Anti-Nucleosome AAb Testing}

$\checkmark$ In case of SLE suspicion and ANA > 1/160 and negative antidsDNA AAb

$\checkmark$ In the follow-up of SLE patients when positive at time of diagnosis (the same test in the same laboratory should always be used in this setting)

\section{Anti-Sm AAb}

Sm proteins are linked to RNA in the nuclear compartment. Characterized by nuclear coarse speckled pattern on Hep 2 cells (47), anti-Sm AAbs are present in $15-55.5 \%$ of SLE patients (37-39, 61). These AAbs have a low sensitivity (10-55\%) but are very specific for SLE (98-100\% according to the test used and to the studied population) and are therefore used in the classification criteria $(31,49,62)$.

The main usefulness of anti-Sm AAb detection seems to be in the subset of patients with SLE but without anti-dsDNA AAb, for whom they are present in $14.8 \%$ of cases (63). The anti-Sm AAb highlighting in SLE seems to be associated with lupus nephritis $(52,64)$ and with a poorer prognosis if they are present at the onset of kidney disease (65) and with a higher clinical relevance if they are associated with anti-dsDNA AAb $(52,53)$. In this line, a recent study showed that the association of a low concentration of complement fraction $\mathrm{C} 3$ and signs of complement activity $(\mathrm{CH} 50)$, together with a high rate of anti-Sm AAb is predictive of lupus nephritis (66). Furthermore, anti-Sm AAbs are mostly expressed in association with anti-RNP (see below) AAb (67). In contrast to anti-dsDNA and anti-nucleosome AAb, anti-Sm AAb level does not correlate with disease activity $(68,69)$.

\section{Clinical Usefulness of Anti-Sm AAb Testing}

$\checkmark$ In case of SLE suspicion and ANA > 1/160 and negative antiDNA AAb

$\checkmark$ Not useful in the follow-up of SLE patients

$\rightarrow$ Association with lupus nephritis

\section{Anti-Histone AAb}

Histones are proteins strongly linked to DNA allowing its compaction, thus forming the nucleosome structure. AAb directed against histone are associated with nuclear homogenous pattern on Hep2 cells (47). In drug-induced SLE such as procainamide, hydralazine, and quinine (70), about $95 \%$ of these patients develop anti-histone $\mathrm{AAb}$, whereas these AAbs are only detected in $50-81 \%$ of cases of primary SLE $(37,71,72)$.

Generally, drug-induced SLE regresses with treatment interruption, and the production of anti-histone $\mathrm{AAb}$ decreases alongside the activity of the disease $(70,73,74)$.

\section{Clinical Usefulness of Anti-Histone AAb Testing}

$\checkmark$ In case of drug-induced SLE

$\checkmark$ Decreased rate associated with regression of drug-induced SLE

\section{Anti-Ro and Anti-La AAb}

Anti-Ro (also called anti-SSa) and anti-La (also called anti-SSb) AAbs are often associated with SS but can also occur in SLE with a prevalence between 36 and $64 \%$ and between 8 and $33.6 \%$ for anti-Ro AAb and anti-La AAb, respectively $(37,38,61,75,76)$. These antibodies are detected in sera about 3.6 years before SLE diagnosis (2) and commonly give a nuclear fine-speckled pattern on Hep2 cells (47).

In SLE, they are associated with skin $(75,77)$ and hematologic manifestations such as cytopenia (78). Furthermore, these AAbs are responsible for neonatal lupus by transplacental passage with cardiac, cutaneous, hematologic, hepatobiliary, and neurologic involvement (79). Neonatal lupus occurs in only $2 \%$ of female patients with anti-Ro/SSa or anti-La/SSb $(80,81)$. Maternal autoimmune disease associated with neonatal lupus development is not always SLE, since maternal SLE is responsible for only $15-50 \%$ of neonatal lupus cases $(79,82)$. AAbs directed against the subunit $52 \mathrm{kDa}$ of Ro are associated with a higher risk of congenital heart block (CHB) (41). In more than $90 \%$ of neonatal lupus cases, AAb regress within 9 months (82) and only few infants will develop authentic SLE $(80,81)$. The risk of CHB in these infants may be prevented by maternal treatment with hydroxychloroquine during pregnancy $(83,84)$. The sensitivity of anti-SSb for SLE is lower than in SS, about $25 \%$ and the specificity about $97 \%$ (85).

Adult patients with anti-Ro/SSa-positive CTD show a high prevalence of QTc interval prolongation (86), with a direct correlation between anti-Ro52 kDa level and QTc duration (87). In fact, anti-Ro/SSa-positive patients have a particularly high risk of developing complex ventricular arrhythmias (88). 


\section{Clinical Usefulness of Anti-Ro and Anti-La AAb Testing}

$\checkmark$ In case of skin and hematologic manifestations

$>$ Association with $\mathrm{CHB}$

\section{Anti-RNP AAb}

Anti-RNP AAbs are found in serum from patients with MCTD. In SLE, these AAbs are detected in $23.3-49 \%$ of cases (37-39). These AAbs are frequently associated with nuclear coarse speckled pattern on Hep2 cells (47). Clinical sensitivity in SLE is between 8 and $69 \%$, with a specificity between 25 and $82 \%$ (62). In contrast with other SLE AAb, anti-RNP AAbs are detected within the year preceding SLE diagnosis (2). However, up to now, correlation with SLE phenotype remains to be clarified.

\section{Clinical Usefulness of Anti-RNP AAb Testing}

$\checkmark$ No specific phenotype in SLE

$\checkmark$ Useless for follow-up

\section{Non-Antinuclear AAb Frequently Observed in SLE}

\section{Anti-C1q AAb}

Patients with genetic defect in C1q expression have an increased risk to develop a lupus-like disease (89). Anti-C1q AAbs are found in $4-60 \%$ of SLE patients, and their prevalence increase with aging (90-93).

High production of anti-C1q AAb is associated with membranoproliferative glomerulonephritis development with 28 and $92 \%$ of sensitivity and specificity, respectively (94-97).

These AAbs are detected 2-6 months before lupus nephritis onset (98-100). By contrast, the absence of anti-C1q AAb is associated with less kidney involvement during SLE course (101). These AAbs are also observed in hypocomplementemic urticarial vasculitis associated or not with SLE (also called McDuffie syndrome) (102).

\section{Clinical Usefulness of Anti-C1q AAb Testing}

$\checkmark$ In case of lupus nephritis

$\checkmark$ Also seen in hypocomplementemic urticarial vasculitis

\section{Anti-Ribosomal P AAb}

Substance $\mathrm{P}$ is a neuropeptide that acts as a neurotransmitter and a neuromodulator. Anti-ribosomal P AAb may be detected by very dense fine granular cytoplasmic pattern when testing for ANA on Hep2 cells (47). These AAbs are detected in 12-20\% of SLE patients $(37,103,104)$ and are associated with disease activity and with neuropsychiatric involvement (105-108). The specificity is between 97 and $100 \%$, and the sensitivity is about $36 \%(103,104,109)$.

\section{Clinical Usefulness of Anti-Ribosomal P AAb Testing}

- In case of neuropsychiatric lupus

$\checkmark$ Useless for follow-up

\section{Antiphospholipid (APL) AAb}

The antiphospholipid syndrome (APS) is observed in $29-46 \%$ of SLE patients (110). APS is defined by pregnancy morbidity (mainly fetal losses) and thromboses (arterial and/or venous) in association with the presence of at least one APL AAb [lupus anticoagulant, anticardiolipin (IgM or IgG), and anti- $\beta 2$ glycoprotein I (IgM or IgG) AAb] on two or more occasions at least 12 weeks apart (111). Some non-thrombotic manifestations such as thrombocytopenia, livedo reticularis, renal microangiopathy, and myelitis can occur in APS but do not belong to classification criteria (112). In SLE, lupus anticoagulant and anticardiolipin are present, respectively, in about 40 and $30 \%$ of cases (with or without APS in the same proportion) $(113,114)$.

Patients having SLE with APS have a threefold higher risk than those without APL to develop a Libman-Sacks endocarditis (115, 116), an increased risk of vascular events (such as thrombosis) and death $(113,114,117)$, and a higher risk to develop pulmonary hypertension (118). A global antiphospholipid score is currently developed in SLE to predict thrombotic risk (119).

\section{Clinical Usefulness of Anti-APL AAb Testing}

$\checkmark$ In all SLE patients at diagnosis

$\checkmark$ In all SLE patients regularly during the follow-up and in case of vascular thrombosis, and/or pregnancy morbidity

\section{Anti-Aquaporin 4 (AQP4) AAb}

Aquaporin 4 is the main water channel in the brain and is also responsible for glutamate and potassium regulation in the blood-brain barrier, synapses, and paranodes adjacent to the nodes of Ranvier. Anti-AQP4 AAb is well known to be specific to neuromyelitis optica (NMO), also called Devic's syndrome (120).

These AAbs can be detected in SLE and are associated with authentic NMO or atypical NMO (myelitis alone or optic neuritis alone) $(121,122)$. Anti-AQP4 AAb seem to be strongly associated with anti-Ro/SSa AAb and also, to a lesser extent, anti-dsDNA AAb (122, 123). Nevertheless, these AAbs can also be detected in SLE and persist for years without concurrent clinical or radiological NMO signs (124). These AAbs can be evidenced in the serum, but their detection in the cerebrospinal fluid from patients allows a higher sensitivity and specificity of the test (125).

\section{Clinical Usefulness of Anti-AQP4 AAb Testing}

$\checkmark$ Useless for diagnosis

$\rightarrow$ Only if NMO signs

\section{SJÖGREN'S SYNDROME-ASSOCIATED AAb}

Sjögren's syndrome is a CTD affecting mainly women, and whose main feature is sicca syndrome. Various organs can be involved in severe forms. Classification criteria include both clinical and immunological parameters (126). Two different forms are observed: primary SS and secondary SS, which is associated with other CTD. The different AAbs observed in patients' sera and their main features are summarized in Table 3. 
TABLE 3 | AAb associated with Sjögren's syndrome.

\begin{tabular}{lcccl}
\hline AAb & Prevalence & Sensitivity & Specificity & Features \\
\hline Anti-Ro52 & $33-77.1 \%$ & $42 \%$ & $100 \%$ & $\mathrm{CHB}++$ \\
& $(130-134)$ & $(130)$ & $(130)$ & \\
Anti-Ro60 & $33-77.1 \%$ & $51 \%$ & $98 \%$ & $\mathrm{CHB}$ \\
& $(130-134)$ & $(130)$ & $(130)$ & \\
Anti-La/SSb & $23-47.8 \%$ & $29 \%$ & $99 \%$ & Doubt on \\
& $(130-134)$ & $(130)$ & $(130)$ & pathogenicity \\
Anti- $\alpha$-fodrin & $98 \%$ & $40 \%$ & $80 \%$ & - \\
& $(141-143)$ & $(141-143)$ & $(141-143)$ & \\
\hline
\end{tabular}

$C H B$, congenital heart block; $A A b$, autoantibody.

\section{ANA in SS}

Antinuclear antibody prevalence is estimated between 41.9 and $64 \%$ in this disease (127-130). Nevertheless, important discrepancies are observed in the immunological presentation of these patients because the detection of AAb is not mandatory for diagnosis (126). Patients producing high level of ANA with anti-Ro/ $\mathrm{SSa}$ and/or anti-La/SSb AAb display a more severe disease with various organ involvements.

\section{Clinical Usefulness of ANA Testing}

D Distribution disparity because of classification criteria of SS (immunologic criteria not always required in presence of sicca syndrome and histopathology)

D Importantly, ANAs are useless in SS follow-up.

\section{Targets of ANA in SS}

The two main antigens recognized by AAb in SS patients are the $\mathrm{Ro} / \mathrm{SSa}$ (with two subunits, one of $52 \mathrm{kDa}$ and one of $60 \mathrm{kDa}$ ) and the La/SSb antigens. The detection of either anti-Ro/SSa and/or anti-La/SSb AAb constitutes one of the classification criteria but their presence is not mandatory for diagnosis (126). These AAbs are evidenced $4-7$ years before SS diagnosis $(3,130)$.

The sensitivity of anti-Ro52, anti-Ro60, and anti-La is estimated at about 42,51 , and $29 \%$, respectively, whereas the specificity is estimated at about 100, 98, and 99\%, respectively (130).

Anti-Ro/SSa AAbs are detected in $33-77.1 \%$ of primary SS, whereas anti-La/SSb AAbs are present in $23-47.8 \%$ of primary SS (130-134). Anti-Ro/SSa AAb can be observed without anti-La/SSb $\mathrm{AAb}$ in patients' sera, conversely anti-La/SSb alone are rarely evidenced (133). Of note, a recent study reported that the diagnosis of SS was unlikely in patients who had only anti-La/SSb AAb without any anti-Ro/SSa AAb (135).

Concerning disease features, patients displaying both anti-Ro/ $\mathrm{SSa}$ and anti-La/SSb AAbs are more at risk to develop a non-Hodgkin lymphoma, whereas the absence of those AAbs seems to be associated with a better prognosis (136). In pregnant women, anti-Ro/ $\mathrm{SSa} \mathrm{AAb}$ can induce a high-degree atrioventricular block in fetus in $1-2 \%$ of pregnancies $(137,138)$. This conduction defect seems to be mainly due to anti-52 $\mathrm{kDa}$ Ro/SSa AAb $(41,139)$. Infants of mothers with SS represent $20-30 \%$ of neonatal lupus cases $(79,82)$. Except for cardiac involvement, neonatal lupus signs are completely solved in most of these infants at 9 months of life (82).

In primary SS, anti-Ro/SSa and anti-La/SSb AAbs are associated with earlier disease onset, longer disease duration, greater severity of glandular symptoms, and higher prevalence of extraglandular manifestations (140).

As described previously, adult patients with anti-Ro/SSapositive CTD show a high prevalence of QTc interval prolongation (86), with a direct correlation between anti-Ro52 kDa level and QTc duration (87). These findings suggest that anti-Ro/ SSa-positive patients may have a particularly high risk of developing life-threatening arrhythmias. In fact, anti-Ro/SSa-positive patients have a particularly high risk of developing complex ventricular arrhythmias (88).

\section{Clinical Usefulness of Anti-Ro and Anti-La AAb Testing}

$\checkmark$ Association with disease severity (risk of non-Hodgkin lymphoma)

- Association with CHB (mostly anti-Ro52) and neonatal lupus by transplacental passage, necessity of screening test and cardiac fetal follow-up in pregnant women at risk

$\checkmark$ Useless for follow-up

\section{Non-Antinuclear AAb Observed in SS Anti-Alpha-Fodrin AAb}

Alpha-fodrin is an intracellular, actin-binding, organ-specific protein of the cytoskeleton. AAb directed against $\alpha$-fodrin can be detected in SS in $98 \%$ of cases with a sensitivity of about $40 \%$ and a specificity of about $80 \%(141-143)$. This kind of AAb can also be detected in SLE patients' sera $(141,144)$.

These AAbs do not seem to be associated with disease activity or clinical manifestation (145). Anti- $\alpha$-fodrin AAb could be useful in SS diagnosis when both anti-Ro/SSa and anti-La/SSb were not detected (146).

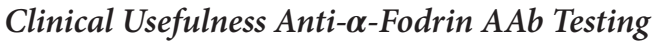

$\checkmark$ Useful for diagnosis in absence of anti-Ro/SSa and anti-La/SSb $\mathrm{AAb}$

$\checkmark$ Useless for follow-up

\section{Anti-AQP4 AAb}

As shown previously, anti-AQP4 AAbs are associated with NMO, also called Devic's syndrome (120) but can also be detected in SS in association with anti-Ro/SSa AAb in most of cases (122, 123). These AAbs in SS are associated with cranial/peripheral neuropathy, authentic NMO or atypical NMO (myelitis alone or optic neuritis alone) $(121,122)$. These AAbs can be evidenced both in the serum and in the cerebrospinal fluid (125).

\section{Clinical Usefulness of Anti-AQP4 AAb Testing}

$\checkmark$ Useless for diagnosis

$\rightarrow$ Only if NMO signs

\section{SYSTEMIC SCLEROSIS-ASSOCIATED AAb}

Systemic sclerosis is a CTD characterized by fibrosis, vasculopathy, and autoimmunity. Clinical and immunological expressions of the disease are highly heterogeneous since a large 
variety of organs can be involved, and various AAbs may be detected in the sera of patients with SSc. Some correlations have been observed between clinical expression and AAb type. In addition, some AAbs are listed in the European League Against Rheumatism (EULAR) classification criteria (147). The association of the different antibodies with the SSc variants is detailed in Table 4.

\section{ANA in SSc}

Antinuclear antibody prevalence is high in SSc, since about $95 \%$ of patients' sera display such AAb (148-150). Various nuclear proteins can be targeted in SSc. Topoisomerase I, centromeric proteins, and RNA polymerase III represent the three most frequent autoantigens recognized in SSc, but numerous other antigens can be identified. Surprisingly and unexplainedly, the production of two different AAbs by a single patient is exceptional (151).

\section{Clinical Usefulness of ANA Testing}

$\checkmark$ In case of SSc suspicion given clinical symptoms, negative ANA in suspicion of SSc makes the diagnosis unlikely.

D Importantly, ANAs are useless in SSc follow-up as they remain positive whatever disease activity.

\section{Targets of ANA in SSc Anti-DNA Topoisomerase I AAb (Anti-Scl70 AAb)}

Type I DNA topoisomerases are enzymes that cut one of the two strands of double-stranded-DNA, relax the strand and reanneal the strand. Anti-DNA topoisomerase I AAbs are detected in $30.1-41.2 \%$ of SSc sera $(150,152,153)$ with a sensitivity estimated about $43 \%$ and a specificity about $90 \%$ (154). Classically, the associated immunofluorescence pattern on Hep2 cells is speckled and nucleolar $(155,156)$.
These AAbs are associated with diffuse systemic sclerosis $(\mathrm{dSSc})$ and with a higher risk of pulmonary fibrosis (PF) (157, 158). Two studies reported that anti-Scl70 (a topoisomerase I protein) AAb levels were correlated with disease activity (159) and that negativation of their detection was associated with a better prognosis (160). Nevertheless, these results remain controversial, and their follow-up during disease evolution is not anymore recommended nowadays. Survival rate at 10 years after diagnosis in patients producing those AAbs is estimated at $66 \%(161)$.

\section{Clinical Usefulness of Anti-Scl70 AAb Testing}

$\checkmark$ Association with diffuse SSc and PF

$\checkmark$ Not recommended for follow-up nowadays

\section{Anti-Centromere AAb}

The centromere is a part of the chromosomal structure that links a pair of sister chromatids. Anti-centromere AAbs are detected in $28.2-36.9 \%$ of SSc patients $(150,152,153)$ with a sensitivity estimated about $44 \%$ and a specificity about 93\% (154).

These AAbs are associated with limited systemic sclerosis (ISSc) and with a higher risk to develop pulmonary arterial hypertension $(\mathrm{PAH})(157,158,162)$. Survival rate at 10 years of patients with anti-centromere AAb, about 93\%, is better the one those from patients with anti-Scl70 AAb (161).

\section{Clinical Usefulness of Anti-Centromere AAb Testing}

Association with limited SSc with a good prognosis

$\rightarrow$ Association with $\mathrm{PAH}$

D Useless for follow-up, not correlated with disease activity

TABLE 4 | AAb associated with systemic sclerosis (SSc).

\begin{tabular}{|c|c|c|c|c|}
\hline AAb & Prevalence & Sensitivity & Specificity & Clinical features \\
\hline Anti-Scl70/DNA topoisomerase I & $\begin{array}{c}30.1-41.2 \% \\
(150,152,153)\end{array}$ & $\begin{array}{l}43 \% \\
(154)\end{array}$ & $\begin{array}{l}90 \% \\
(154)\end{array}$ & $\begin{array}{l}\text { Diffuse SSc } \\
\text { PF }\end{array}$ \\
\hline Anti-centromere & $\begin{array}{c}28.2-36.9 \% \\
(150,152,153)\end{array}$ & $\begin{array}{l}44 \% \\
(154)\end{array}$ & $\begin{array}{l}93 \% \\
(154)\end{array}$ & $\begin{array}{l}\text { Limited SSc } \\
\mathrm{PAH}\end{array}$ \\
\hline Anti-RNA polymerase III & $\begin{array}{c}3.8-19.4 \% \\
(152,153,163,164)\end{array}$ & $\begin{array}{l}38 \% \\
(154)\end{array}$ & $\begin{array}{l}94 \% \\
(154)\end{array}$ & $\begin{array}{l}\text { Diffuse SSc } \\
\text { Scleroderma renal crisis }\end{array}$ \\
\hline Anti-U1-RNP & $\begin{array}{l}4.8-4.9 \% \\
(152,153)\end{array}$ & - & - & $\begin{array}{l}\text { Limited SSC } \\
\text { PAH } \\
\text { Overlap with SLE or MCTD }\end{array}$ \\
\hline Anti-U3-RNP & $\begin{array}{c}1.4-8 \% \\
16-18.5 \text { in AA } \\
(152,153,181-183)\end{array}$ & $\begin{array}{r}12 \% \\
(154)\end{array}$ & $\begin{array}{l}97 \% \\
(154)\end{array}$ & $\begin{array}{l}\text { Diffuse SSc } \\
\text { PAH }\end{array}$ \\
\hline Anti-Pm/Scl & $\begin{array}{c}3.1-13 \% \\
(150,152,173)\end{array}$ & $\begin{array}{c}12.5 \% \\
(154,174)\end{array}$ & $\begin{array}{c}98 \% \\
(154,174)\end{array}$ & $\begin{array}{l}\text { Limited SSc } \\
\text { Overlap with myositis } \\
\text { PF } \\
\text { Digital ulcers }\end{array}$ \\
\hline Anti-Ku & $\begin{array}{c}1.1-4.6 \% \\
(150,152,176,177)\end{array}$ & - & - & $\begin{array}{l}\text { Limited SSc } \\
\text { Overlap with myositis }\end{array}$ \\
\hline Anti-Th/To & $\begin{array}{l}0.2-3.4 \% \\
(152,153)\end{array}$ & - & - & $\begin{array}{l}\text { Limited SSc } \\
\mathrm{PAH}\end{array}$ \\
\hline Anti-NOR90 & $\begin{array}{c}6 \% \\
(150)\end{array}$ & - & - & $\begin{array}{l}\text { Limited SSc } \\
\text { PF }\end{array}$ \\
\hline
\end{tabular}

PAH, pulmonary arterial hypertension; AA, Afro-American population; SLE, systemic lupus erythematosus; MCTD, mixed connective tissue disease; PF, pulmonary fibrosis; AAb, autoantibody. 


\section{Anti-RNA Polymerase AAb}

RNA polymerase III is used to transcribe DNA into small RNA. Characterized by fine-speckled nucleoplasmic stain with additional occasional bright dots on Hep2 cells (47), anti-RNA polymerase III AAbs are detected in $3.8-19.4 \%$ of SSc sera, depending on ethnic group $(152,153,163,164)$ with a sensitivity about $38 \%$ and a specificity about $94 \%$ (154).

These AAbs are associated with dSSc and with a higher risk of scleroderma renal crisis, gastric antral vascular ectasia (also called watermelon stomach), and cancer (mainly synchronous breast cancer) (157, 165-167). Patients with anti-RNA polymerase III have a higher Rodnan skin score (used for skin fibrosis graduation) than patients with other AAbs and also are more likely to be rapid progressor $(167,168)$. Survival rate at 10 years in patients producing these AAbs is low, about $30 \%$ (161).

Other polymerases can be targeted by self-reactive lymphocytes. Anti-RNA polymerase I AAb may also be produced by SSc patients, mainly in association with anti-RNA polymerase III AAb production. Of note, the detection of isolated anti-RNA polymerase I AAb is not associated with SSc (169). The presence of both anti-RNA polymerase I/III AAb is also associated with cancer and scleroderma renal crisis $(170,171)$. Furthermore, the concomitant production of anti-RNA polymerase II and III $\mathrm{AAb}$ seems to increase the risk of scleroderma renal crisis as compare to the production of anti-RNA polymerase III AAb alone (172).

\section{Clinical Usefulness of Anti-RNA Polymerase AAb Testing}

D Mostly concerning anti-RNA polymerase III AAb in clinical practice

$\checkmark$ Association with risk of scleroderma renal crisis

D Cancer must be search (mostly breast cancer)

$\checkmark$ Useless for follow-up, not correlated with disease activity

\section{Anti-Pm/Scl AAb}

Anti-Pm/Scl AAbs are detected in 3.1-13\% of SSc patients (150, $152,173)$ with a sensitivity about $12.5 \%$ and a specificity about 98\% (154, 174). Anti-Pm/Scl AAbs are distinguished by homogeneous nucleolar pattern by IFI (47).

These AAbs are associated with ISSc, overlap syndrome with myositis, PF, and digital ulcers $(157,174,175)$. By contrast, PAH is less frequent in patients producing those AAbs (174).

\section{Clinical Usefulness of Anti-Pm/Scl AAb Testing}

Dostly seen in overlap syndrome with myositis

D Less likely to be associated with PAH

$\checkmark$ Useless for follow-up, not correlated with disease activity

\section{Anti-Ku AAb}

Anti-Ku AAbs are detected in 1.1-4.6\% of SSc sera (150, 152, $176,177)$, frequently associated with nuclear fine-speckled pattern on Hep2 cells (47). They are associated with ISSc and with a higher risk of myositis and interstitial lung disease (ILD) (150, $157,177)$, the absence of digital ulcers and telangiectasia (176).

\section{Clinical Usefulness of Anti-Ku AAb Testing}

$\checkmark$ Rarely seen in practice

- Useless for follow-up, not correlated with disease activity

\section{Anti-Th/To AAb}

Anti-Th/To AAb can be detected in $0.2-3.4 \%$ of SSc patients $(152,153)$ with homogeneous nucleolar fluorescence such as anti-Pm/Scl AAb (47). These AAbs are associated with ISSc and a higher risk of PAH $(157,162)$. A recent long-term follow-up study evidenced that patients with anti-Th/To AAbs are more likely to develop pulmonary hypertension (PAH or pulmonary hypertension secondary to ILD) with a better prognosis and less joint involvement than other SSc patients with other AAbs (178).

\section{Clinical Usefulness of Anti-Th/To AAb Testing}

$\checkmark$ Rarely seen in practice

D Association with pulmonary hypertension (PAH or pulmonary hypertension secondary to ILD)

$\rightarrow$ Useless for follow-up, not correlated with disease activity

\section{Anti-RNP AAb}

Anti-U1-RNP AAbs, distinguished by nuclear coarse speckled pattern by IFI (47), are found in $4.8-4.9 \%$ of SSc patients (152, 153). They are associated with ISSc and with a higher risk to develop PAH (157). Patients with anti-U1-RNP AAb-associated $\mathrm{PAH}$ seems to have a better prognosis than SSc related-PAH associated with other antibodies (179). The presence of this kind of AAb evokes an overlap syndrome with other autoimmune diseases, mostly SLE and MCTD (180).

Anti-U3-RNP AAbs (also called anti-fibrillarin AAb), distinguished by clumpy nucleolar pattern on Hep 2 cells (47), are globally detected in 1.4 and $8 \%$ of SSc cases, with important differences between the populations studied (150, $152,153,181-183)$ with a sensitivity about $12 \%$ and a specificity about $97 \%$ (154). However, these AAbs are more frequently detected in Afro-American people (16-18.5\%) $(183,184)$. Fibrillarin is a component of several ribonucleoproteins including a nucleolar small nuclear ribonucleoprotein. These AAbs are frequently associated with rapidly progressive $\mathrm{dSSc}$ (with a Rodnan skin score lower than in other dSSc), muscular involvement, and a higher risk of PAH (182). The presence of anti-fibrillarin AAb in Afro-American population is associated with a higher risk of digital ulcers, pericarditis, and gastrointestinal involvement, but in contrast, with less pulmonary involvement (184).

\section{Clinical Usefulness of Anti-RNP AAb Testing}

- In practice, always ask for both U1 and U3-RNP AAb because of clinical differences

Anti-U1-RNP AAb associated with PAH

$\rightarrow$ Anti-U3-RNP AAb frequent in Afro-American people and associated with diffuse SSc

Useless for follow-up, not correlated with disease activity 


\section{Anti-Ro/SSa AAb}

Anti-Ro/SSa AAbs, also evidenced in SLE and in the SS, are detected in 15-19\% of SSc patients, especially AAb directed against the $52 \mathrm{kDa}$ subunit (185). Conversely, anti-SSb AAbs are rarely observed in SSc.

Patients with anti-Ro/SSa AAb show a high prevalence of QTc interval prolongation correlated with anti-Ro52 $\mathrm{kDa}$ level and with a higher risk to develop complex ventricular arrhythmias (86-88).

\section{Clinical Usefulness of Anti-Ro and Anti-La AAb Testing}

$\checkmark$ Not associated with clinical phenotype

D Useless for follow-up, not correlated with disease activity

\section{Anti-NOR90 AAb}

Nucleolus organizer regions (NORs) are chromosomal regions crucial for the formation of the nucleolus. Anti-NOR90 AAbs are directed against a $90 \mathrm{kDa}$ component of NOR and are found in about $6 \%$ of SSc patients (150). These AAbs are associated with punctate nucleolar fluorescence on Hep2 cells (47). Anti-NOR90 AAbs seem to be associated with ISSc and PF (150). These AAbs can also be detected in patients with SLE, SS, and RA (186).

\section{Clinical Usefulness of Anti-NOR90 AAb Testing}

$\checkmark$ Rarely seen in practice and not specific to SSc

$\checkmark$ Useless for follow-up, not correlated with disease activity

\section{Anti-Histone AAb}

Anti-histone AAbs are evidenced in some SSc sera and seem to be associated with critical internal organ involvement such as cardiac, pulmonary, and renal involvement, and with a decreased survival rate $(187,188)$.

\section{Clinical Usefulness of Anti-Histone AAb Testing}

$\checkmark$ Rarely seen in practice

Useless for follow-up, not correlated with disease activity

\section{Non-Antinuclear AAb Frequently Observed in SSc}

Anti-Citrullinated Protein/Peptide AAb (ACPA)

These AAbs are commonly observed in patients with RA but can also be detected in $10 \%$ of SSc patients (189). In a recent metaanalysis, the presence of this kind of AAb in the setting of SSc was associated with dSSc, erosive arthritis, and PF (189).

\section{Clinical Usefulness of ACPA Testing}

D Association with erosive arthritis (means overlap syndrome with RA?)

Useless for follow-up, not correlated with disease activity

\section{MYOSITIS-ASSOCIATED AAb}

Myositis are characterized by a high phenotypic heterogeneity ranging from isolated muscle involvement to various organs manifestations such as ILD, arthritis, or overlap syndrome with other autoimmune diseases. AAbs are currently evidenced in $60-80 \%$ of these patients $(190,191)$. AAbs observed in myositis can be divided in two different groups: myositis-specific AAb (mostly non-ANA) and AAb that can be also observed in other CTD. Four distinct forms of myositis with specific AAbs are currently recognized depending on their clinical and histological features: polymyositis [mainly the antisynthetase syndrome (ASS)], necrotizing myopathy (NM), dermatomyositis (DM), and inclusion body myositis (IBM) $(192,193)$. In all of these myositis manifestations, only one $\mathrm{AAb}$ is detectable in each patient (194). The different myositis-specific AAbs are recapitulated in Table 5.

TABLE 5 | AAb associated with myositis [antisynthetase syndrome (ASS), necrotizing myopathy (NM), dermatomyositis (DM), and inclusion body myositis (IBM)].

\begin{tabular}{|c|c|c|c|}
\hline $\begin{array}{l}\text { Kind of } \\
\text { myositis }\end{array}$ & $\mathbf{A A b}$ & Prevalence & $\begin{array}{l}\text { Clinical and therapeutical } \\
\text { features }\end{array}$ \\
\hline \multirow[t]{4}{*}{$\begin{array}{l}\text { Anti-synthetase } \\
\text { syndrome }\end{array}$} & Anti-Jo1 & $\begin{array}{c}70 \% \\
(194,197)\end{array}$ & $\begin{array}{l}\text { Better prognosis } \\
\text { More likely associated with } \\
\text { myositis than ILD }\end{array}$ \\
\hline & Anti-PL7 & $\begin{array}{c}10 \% \\
(194,197)\end{array}$ & Poor prognosis \\
\hline & Anti-PL12 & $\begin{array}{c}15 \% \\
(194,197)\end{array}$ & $\begin{array}{l}\text { More likely associated with ILD } \\
\text { than myositis }\end{array}$ \\
\hline & $\begin{array}{l}\text { Anti-EJ } \\
\text { Anti-OJ } \\
\text { Anti-KS } \\
\text { Anti-ZO } \\
\text { Anti-HA }\end{array}$ & $\begin{array}{c}<2 \% \\
(194,197)\end{array}$ & - \\
\hline \multirow[t]{2}{*}{$\begin{array}{l}\text { Necrotizing } \\
\text { myopathy }\end{array}$} & $\begin{array}{l}\text { Anti- } \\
\text { HMGCR }\end{array}$ & $\begin{array}{c}12-34 \% \\
(63 \% \text { with } \\
\text { statin history) } \\
(202,205,206)\end{array}$ & $\begin{array}{l}\text { Present in statin-associated } \\
\text { myopathies } \\
\text { Associated with cancer } \\
\text { Correlated with disease activity } \\
\text { Good response to } \\
\text { immunosuppressive treatment } \\
\text { (except for statin naïve patients) }\end{array}$ \\
\hline & Anti-SRP & $\begin{array}{c}18-24 \% \\
(202,205)\end{array}$ & $\begin{array}{l}\text { Correlate with disease activity } \\
\text { Associated with ILD } \\
\text { Poor response to } \\
\text { immunosuppressive treatment }\end{array}$ \\
\hline \multirow[t]{5}{*}{ Dermatomyositis } & $\begin{array}{l}\text { Anti- } \\
\text { TIF1- } \gamma\end{array}$ & $\begin{array}{c}13-38 \% \\
(212,213)\end{array}$ & Strongly associated with cancer \\
\hline & $\begin{array}{l}\text { Anti- } \\
\text { NXP2 }\end{array}$ & $\begin{array}{c}17 \% \\
(212,216)\end{array}$ & $\begin{array}{l}\text { Associated with cancer } \\
\text { Calcinosis and muscle atrophy } \\
\text { in juvenile DM }\end{array}$ \\
\hline & $\begin{array}{l}\text { Anti- } \\
\text { MDA5 }\end{array}$ & $\begin{array}{c}10 \% \\
(40 \% \text { Asian } \\
\text { population) } \\
(219,220)\end{array}$ & $\begin{array}{l}\text { Associated with severe ILD and } \\
\text { skin ulcerations } \\
\text { Correlate with disease activity } \\
\text { Poor prognosis }\end{array}$ \\
\hline & Anti-SAE & $\begin{array}{c}7-8 \% \\
(225,226)\end{array}$ & Severe dysphagia \\
\hline & Anti-Mi2 & $\begin{array}{c}18-35 \% \\
(228,229)\end{array}$ & $\begin{array}{l}\text { Good response to } \\
\text { immunosuppressive treatments }\end{array}$ \\
\hline $\begin{array}{l}\text { Inclusion body } \\
\text { myositis }\end{array}$ & $\begin{array}{l}\text { Anti- } \\
\text { CN1a }\end{array}$ & $\begin{array}{l}30 \% \\
(231)\end{array}$ & $\begin{array}{l}\text { Single AAb described in IBM up } \\
\text { to now }\end{array}$ \\
\hline
\end{tabular}

ILD, interstitial lung disease; $A A b$, autoantibody. 


\section{Anti-Synthetase Syndrome-Associated AAb}

Antisynthetase syndrome is characterized clinically by myositis, ILD, arthritis, Raynaud's phenomenon, mechanic's hands, fever, and immunologically by the presence of an anti-tRNA synthetase AAb (195). In contrast with other groups of myositis, no correlation with cancer was made in ASS. Amino-acyl-tRNA-synthetases are enzymes that attach the appropriate amino acid onto its tRNA.

The different AAbs describe up to now are the anti-Jo1, antiPL7, anti-PL12, anti-EJ, anti-OJ, anti-KS, anti-Zo, and anti-Ha AAb. Such AAb, associated with cytoplasmic speckled or finespeckled fluorescence (47), are detected in about $30 \%$ of ASS cases (196). Anti-Jol AAb is the most frequently evidenced in about $70 \%$ of ASS, followed by anti-PL12 AAb in 15\%, anti-PL7 $\mathrm{AAb}$ in 10\%, whereas other ASS-associated AAbs are observed in less than $2 \%$ of the cases $(194,197)$.

The phenotype and the survival rate depend on the protein targeted by the AAb. Anti-PL7 and anti-PL12 AAbs are mostly associated with ILD and with a worst outcome than anti-Jo1 AAb (198). A long-term follow-up study demonstrated that anti-Jo1 AAb-associated myositis preceded the development of ILD, whereas ILD started before anti-PL7 and PL12 AAb-associated myositis (199). Patients with anti-Jo1 AAb less frequently develop sclerodactyly and ILD but display more frequently myositis than patients producing other types of anti-tRNA synthetase AAb (194). Furthermore, the level of anti-Jo1 AAb seems to be modestly correlated with muscle (in particular serum creatine kinase) and joint activity (200).

\section{Clinical Usefulness of ASS AAb Testing}

D In cases of ASS, mostly anti-Jo1, anti-PL7, and PL12 are detected

D Development of myositis first in anti-Jo1 ASS, development of ILD first in anti-PL7 and PL12 ASS

D Useless for follow-up, not correlated with disease activity (except for anti-Jo1)

\section{Necrotizing Myopathy-Associated AAb}

Necrotizing myopathy is characterized by subacute proximal limb muscle weakness, strongly elevated creatine kinase levels, muscle fiber necrosis, and regeneration, phenomenon that can be observed on muscle biopsy specimens (201). The two main AAbs in NM are directed against the signal recognition particle (anti-SRP AAb) and the 3-hydroxy-3-methylglutaryl-coenzyme A reductase (anti-HMGCR AAb). These AAbs are present in about $60 \%$ of cases $(202)$, and both probably play a pathogenic role in the disease $(203,204)$.

\section{Anti-HMGCR AAb}

The 3-hydroxy-3-methylglutaryl-coenzyme A reductase is the rate-limiting enzyme for cholesterol synthesis. The prevalence of anti-HMGCR AAb is of $12-34 \%(202,205)$ and can reach up to $63 \%$ in patients with a past history of treatment by statin (206).

Necrotizing myopathy may be associated with cancer, especially when associated with anti-HMGCR AAb (202).
Anti-HMGCR antibody serum level seems to be correlated with disease activity and with serum creatine kinase level (207). Generally, NM patients with anti-HMGCR AAb have a good response to immunosuppressive treatments but have a tendency to relapse (208). The presence of anti-HMGCR AAb in statinnaive patients is associated with a lower response to treatment (209).

\section{Clinical Usefulness of Anti-HMGCR AAb Testing}

D Strongly associated with NM with past history of statin treatment

$\checkmark$ Cancer must be sought for in presence of one of these AAb

$\checkmark$ Good response to immunosuppressive treatment

$\checkmark$ Useful for follow-up, correlated with disease activity (and serum creatine kinase level)

\section{Anti-SRP AAb}

SRP is a complex of six proteins permitting the translocation of nascent proteins to the endoplasmic reticulum. The prevalence of anti-SRP AAb in NM is of 18-24\% $(202,205)$. Like anti-HMGCR, the level of anti-SRP antibody is correlated with disease activity and with serum creatine kinase level (210). Anti-SRP AAbs share also with anti-HMGCR AAb a cytoplasmic dense fine granular pattern by IFI on HEP2 cells (47).

Patients with anti-SRP AAb seem to have more severe muscle weakness and ILD than patients with anti-HMGCR AAb (211). Finally, NM patients with anti-SRP AAb seem to have a reduced response to usual immunosuppressive treatments than other myopathies (208).

\section{Clinical Usefulness of Anti-SRP AAb Testing}

Association with severe muscle weakness and ILD

$\checkmark$ Poor response to immunosuppressive treatment

Useful for follow-up, correlated with disease activity (and serum creatine kinase level)

\section{Dermatomyositis-Associated AAb}

Dermatomyositis is an inflammatory disease characterized by proximal muscle weakness and skin involvement. Muscle histology is typical with perifascicular atrophy, vasculopathy, and inflammatory infiltrations. In DM, five AAbs have been described. They are directed against transcription intermediary factor 1 gamma (anti-TIF1- $\gamma \mathrm{AAb}$ ), nuclear matrix protein 2 (anti-NXP2 AAb), melanoma differentiation-associated gene 5 (anti-MDA5 AAb), and small ubiquitin-like modifier activating enzyme (anti-SAE AAb), while anti-Mi2 AAbs recognize the nucleosome remodeling histone deacetylase protein complex (NuRD).

\section{Anti-TIF1- $\gamma$ AAb}

The TIF1- $\gamma$ protein (also called TRIM 33 for Tripartite motifcontaining 33) is a transcriptional corepressor that acts as a tumor suppressor protein. The anti-TIF1- $\gamma$ AAb may be detected by nuclear fine-speckled fluorescence on Hep2 cells with a prevalence in DM of $13-38 \%(47,212,213)$. 
The production of AAb directed against this protein is strongly associated with cancer occurrence with a sensitivity of $78 \%$, a specificity of $89 \%$, and positive and negative predictive values of 58 and $95 \%$, respectively $(212,214)$. These patients are also more frequently diagnosed with dysphagia (215).

\section{Clinical Usefulness of Anti-TIF1- $\gamma$ AAb Testing}

$\checkmark$ Cancer must be sought for in presence of these AAb

D Useless for follow-up, not correlated with disease activity

\section{Anti-NXP2 AAb}

The prevalence of anti-NXP2 in DM is of $17 \%(212,216)$. These AAbs are distinguished by multiple nuclear dots on the nucleoplasm of Hep2 cells by IFI (47). As for anti-TIF1- $\gamma$, anti-NXP2 $\mathrm{AAb}$ production is associated with a higher risk of cancer development (212). These AAbs are also associated with calcinosis and muscle atrophy, especially in juvenile DM $(217,218)$.

\section{Clinical Usefulness of Anti-NXP2 AAb Testing}

$\checkmark$ Cancer must be sought for in presence of these AAbs

D Association with calcinosis, mostly in juvenile DM

D Useless for follow-up, not correlated with disease activity

\section{Anti-MDA5 AAb}

MDA5 is an RIG-I-like receptor functioning as a viral-sensing pattern recognition receptor. The prevalence of anti-MDA5 AAb in DM is of $10 \%$ (219) and seems to be higher (about 40\%) in Asian population (220).

The presence of anti-MDA5 AAb is associated with a higher risk of developing an ILD (221). Subsequently, patients with this kind of AAb display poorer prognosis, with approximately $50 \%$ of death by respiratory failure within the first 6 months following diagnosis (222). Clinically, these patients also present with hand swelling, skin ulceration, panniculitis, and palmar papules (219). Serum level of AAb is correlated with disease activity, and it disappears with its remission $(223,224)$.

\section{Clinical Usefulness of Anti-MDA5 AAb Testing}

$\checkmark$ Poor prognosis with respiratory failure

$\checkmark$ Mostly, myositis not at the forefront

$\checkmark$ Useful for follow-up, correlated with disease activity

\section{Anti-SAE AAb}

SAE is implicated in the nuclear-cytosolic transport and in the transcriptional regulation. The prevalence of anti-SAE AAb in $\mathrm{DM}$ is of $7-8 \%(225,226)$ but, in contrast to the anti-MDA5 $\mathrm{AAb}$, the anti-SAE AAbs are less common (about 2\%) in the Asian population (227). Clinically, the presence of these AAbs is associated with severe dysphagia (226).

\section{Clinical Usefulness of Anti-SAE AAb Testing}

$\checkmark$ Association with severe dysphagia

D Useless for follow-up, not correlated with disease activity

\section{Anti-Mi2 AAb}

Anti-Mi2 AAbs target NuRD, a nuclear proteic complex implicated in multiple transcriptional regulatory processes such as histone demethylation, histone deacetylation, and nucleosome mobilization. They are found in $18-35 \%$ of patients with DM $(228,229)$ and are associated with nuclear fine-speckled fluorescence by IFI on Hep2 cells (47).

Patients with anti-Mi2 AAb seem to have better response to immunosuppressive treatment (229).

\section{Clinical Usefulness of Anti-Mi2 AAb Testing}

Not associated with a specific clinical phenotype

D Useless for follow-up, not correlated with disease activity

\section{Inclusion Body Myositis-Associated AAb}

Inclusion body myositis is a myopathy observed in middle-aged patients that leads to a progressive, asymmetric muscle weakness with swallowing troubles (230). Muscle biopsy evidences vacuolated muscle fibers, inflammatory infiltrates, and intracellular deposits of amyloid protein.

Recently, a novel AAb has been identified (231) in one-third of these IBM patients, which recognizes the cytosolic $5^{\prime}$-nucleotidase 1A (anti-CN1a). Nevertheless, these antibodies are also detected in SLE and in SS patients (232). Its presence or absence does not seem to affect disease prognosis nor evolution (233). This myopathy is poorly responsive to immunosuppressive treatment.

\section{Clinical Usefulness of Anti-CN1a AAb Testing}

$\checkmark$ Single AAb described in IBM up to now

$\checkmark$ Useless for follow-up, not correlated with disease activity

\section{RHEUMATOÏD ARTHRITIS-ASSOCIATED AAb}

Rheumatoid arthritis is the most common inflammatory rheumatoid disease with a world prevalence of approximatively $0.5-1 \%$ (234). The disease typically affects small and medium-sized joints symmetrically. The primary lesion is synovitis. Systemic involvement is often observed, with respiratory, cardiovascular, and hematopoietic systems being the more damaging lesioned sites.

\section{Antinuclear AAb in RA}

Antinuclear antibody is not the main type of AAb detected in RA but they are present in about $20 \%$ of cases (128). The ANA detection has no clinical relevance in RA but is useful for treatments. The highlighting of ANA under infliximab is associated with poorer response to treatment (developing antibody directed against infliximab) and a risk to develop induced lupus $(235,236)$.

\section{Clinical Usefulness of ANA Testing}

$\checkmark$ Useless for diagnosis

D Useful in treatment to predict response and complications (induced lupus) 


\section{Non-Antinuclear AAb Frequently Observed in RA}

The two main AAb associated with RA (recapitulated in Table 6) are chronologically rheumatoid factor (RF) and ACPA. Other AAbs [anti-CarP (237) and anti-NOR9 0 (186) $\mathrm{AAb}$ ] are not available in routine practice nowadays. Two main classification criteria are available, based on the presence of both clinical and immunological parameters: the ACR 87 classification (238) and the 2010 classification criteria of the ACR/EULAR (239) collaborative initiative. RF or ACPA measurements between one and three times the upper limit of normal are designated "low"; higher measurements are designated "high." The high measurement increases the probability of positive diagnosis $(238,239)$. RA is typically divided

TABLE 6 | AAb associated with rheumatoid arthritis.

\begin{tabular}{lcccl}
\hline AAb & Prevalence & Sensitivity & Specificity & Features \\
\hline $\begin{array}{l}\text { Rheumatoid } \\
\text { factor }\end{array}$ & $50-70 \%(243)$ & - & $50-95 \%(245)$ & $\begin{array}{l}\text { Associated with } \\
\text { disease activity }\end{array}$ \\
ACPA & $60-70 \%(249)$ & - & $95 \%(243)$ & $\begin{array}{l}\text { Associated with } \\
\text { disease activity } \\
\end{array}$ \\
& & & Erosive arthritis
\end{tabular}

ACPA, anti-citrullinated peptide $A A b ; A A b$, autoantibody.

The term ACPA regroups anti-cyclic citrullinated peptide (anti-CCP) and also

anti-non-cyclic citrullinated peptides AAb. into two subtypes designated "seropositive" and "seronegative" disease, with seropositivity being defined as the presence of AAb. The heritability of RA is currently estimated as $40-65 \%$ for seropositive RA, but lower (20\%) for seronegative disease (240, 241).

\section{Rheumatoid Factor}

Rheumatoid factor is the first well-known RA immunologic marker discover in 1957 (242) that targets the Fc part of human IgG. RFs are present in 50-70\% (243) of patients at diagnosis, with little increase throughout disease course $(234,243)$. There is a correlation between RF titer and radiographic progression (244). The specificity of RF for RA diagnosis depends on clinical context: strong with an articular involvement and low without articular involvement (50-95\%) (245).

Rheumatoid factor can also be found in healthy (elderly) individuals and patients with other autoimmune and infectious diseases (245). Despite this lack of specificity, the presence of RF was one of the seven diagnostic criteria for RA put forward by the ACR in 1987 and is also included in the ACR/EULAR 2010 classification criteria for RA.

\section{Clinical Usefulness of RF Testing}

Useful for diagnosis

Useful in follow-up to predict disease activity

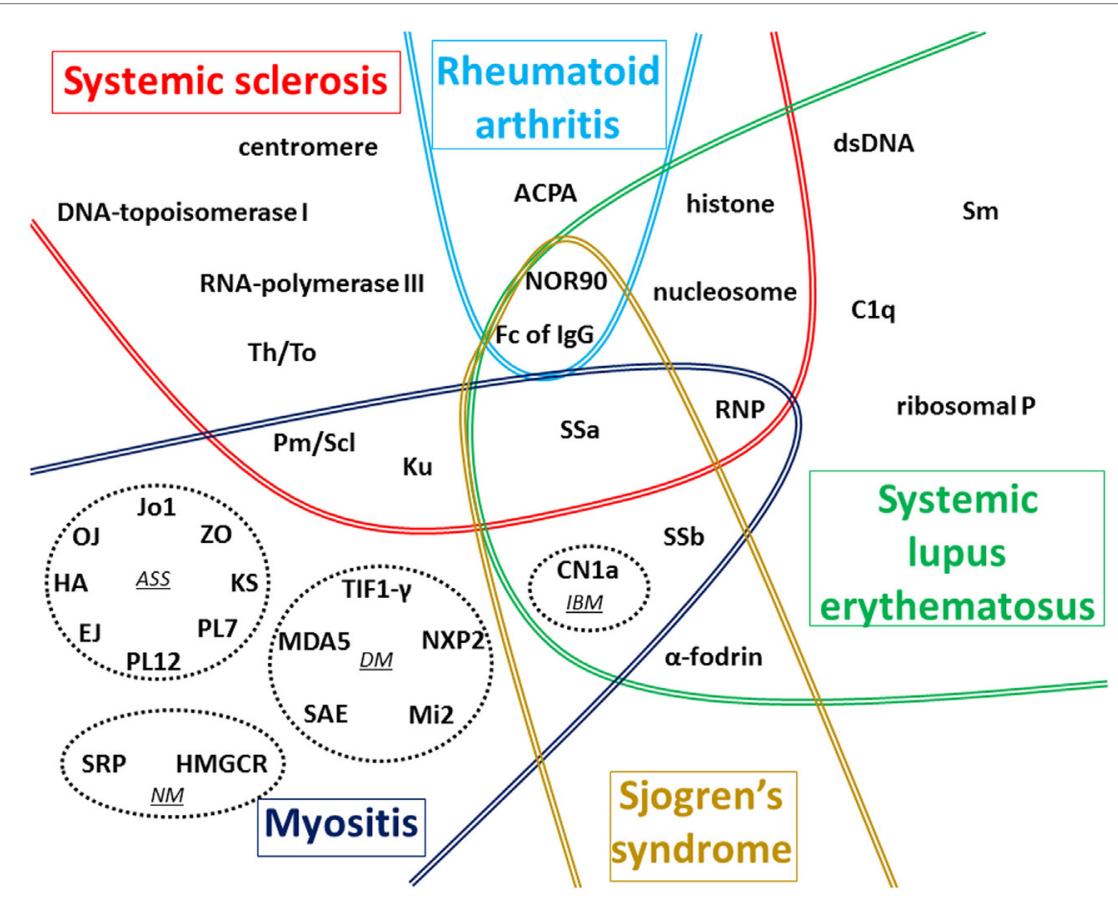

FIGURE 1 | Global vision of autoantigens targeted by autoantibody (AAb) according to the type of connective tissue diseases (CTDs). The main targets of AAb associated with the five CTDs detailed in this review are recapitulated on this figure. In myositis, four distinct forms associated with distinct AAbs are represented in dotted circles: antisynthetase syndrome (ASS), dermatomyositis (DM), necrotizing myopathy (NM), and inclusion body myositis (IBM). In systemic sclerosis (SSc), most AAbs are preferentially associated with one of the two cutaneous forms described: anti-centromere, anti-Th/To, anti-Pm/Scl, anti-Ku, and anti-U1-RNP AAbs are generally associated with limited form of SSc whereas anti-DNA-topoisomerase I, anti-RNA-polymerase III, and anti-U3-RNP AAbs are mostly associated with diffuse cutaneous SSc. The term ACPA regroups anti-cyclic citrullinated peptide and also anti-non-cyclic citrullinated peptides AAb. Fc of IgG corresponds to target of rheumatoid factor. Some AAbs are associated with more than one CTD as shown in the different overlap areas on the figure. 


\section{Anti-Citrullinated Protein/Peptide AAb}

Citrullination is a process by which arginine residues in a given protein are post-translationally modified ("deiminated") in the presence of high calcium concentrations by an enzyme called PAD (peptidylarginine deiminase) $(234,246)$. In 1998, two AAbs present in serum samples from patients with RA that had already been described years earlier (antiperinuclear factor and anti-keratin antibodies) were found to share a common specificity for citrullinated filaggrin (247). First, a cyclic citrullinated peptide (CCP) was developed to improve antigen composition and antibody recognition. Then, new assays were developed to detect non-CCPs, and now the term anti-citrullinated protein/ peptide AAb (ACPA) has thus replaced anti-cyclic citrullinated peptide (anti-CCP) AAb (248).

Using CCPs as antigens, ACPA are detected in $60-70 \%$ of RA patients (249). ACPA appear more specific for RA than RF. The specificity of ACPA is almost of 95\% in RA (243). ACPA can also be detected in patients with SSc (189), psoriatic arthritis, SS, SLE, and MCTD (250).

ACPA are linked to erosive form of RA, and the likelihood of radiographic progression after 5 years is significantly greater among RA patients with ACPA $(\mathrm{OR}=2.5)(251,252)$. Moreover, detection of both RF and ACPA is associated with a more important radiographic progression and a poorer prognostic factor in patients with RA (252). ACPA can be detected in sera several years before clinical onset of arthritis (253). Recently, a new study showed that serological status (ACPA positivity) is a risk factor of serious infusion-related reactions in RA treated by non-TNFtargeted biologics (254).

\section{Clinical Usefulness of Anti-ACPA Testing}

$\checkmark$ Useful for diagnosis

$\checkmark$ Association with erosive arthritis

$\checkmark$ Useful in follow-up to predict disease activity

\section{REFERENCES}

1. Bizzaro N, Tozzoli R, Shoenfeld Y. Are we at a stage to predict autoimmune rheumatic diseases? Arthritis Rheum (2007) 56(6):1736-44. doi:10.1002/ art. 22708

2. Arbuckle MR, McClain MT, Rubertone MV, Scofield RH, Dennis GJ, James JA, et al. Development of autoantibodies before the clinical onset of systemic lupus erythematosus. N Engl J Med (2003) 349(16):1526-33. doi:10.1056/ NEJMoa021933

3. Jonsson R, Theander E, Sjöström B, Brokstad K, Henriksson G. Autoantibodies present before symptom onset in primary Sjögren syndrome. JAMA (2013) 310(17):1854-5. doi:10.1001/jama.2013.278448

4. Wang K-Y, Yang Y-H, Chuang Y-H, Chan P-J, Yu H-H, Lee J-H, et al. The initial manifestations and final diagnosis of patients with high and low titers of antinuclear antibodies after 6 months of follow-up. J Microbiol Immunol Infect (2011) 44(3):222-8. doi:10.1016/j.jmii.2011.01.019

5. Minz RW, Kumar Y, Anand S, Singh S, Bamberi P, Verma S, et al. Antinuclear antibody positive autoimmune disorders in North India: an appraisal. Rheumatol Int (2012) 32(9):2883-8. doi:10.1007/s00296-011-2134-1

6. Selmi C, Ceribelli A, Generali E, Scirè CA, Alborghetti F, Colloredo G, et al. Serum antinuclear and extractable nuclear antigen antibody prevalence and associated morbidity and mortality in the general population over 15 years. Autoimmun Rev (2016) 15(2):162-6. doi:10.1016/j.autrev.2015.10.007

7. Fernandez SAV, Lobo AZC, de Oliveira ZNP, Fukumori LMI, Prigo AM, Rivitti EA. Prevalence of antinuclear autoantibodies in the serum of

\section{CONCLUSION}

Numerous AAbs can be evidenced in the sera of patients with CTD (Figure 1), and new autoantigens are regularly identified in this field of diseases. In the majority of cases, these AAbs are produced before clinical symptoms, but only a minority of these AAbs has been clearly demonstrated to be involved in the pathogenesis of these diseases. The understanding of the implication in pathogenesis of these AAbs still needs to be investigated, notably using animal models, to be able to find new therapeutic targets.

Evidence of these AAbs can help clinicians for disease diagnosis and is therefore frequently mentioned in international classification criteria. Moreover, since some AAbs are correlated with disease activity and/or specific organ involvement, their detection and in some cases their level follow-up can also be a helpful tool in the long-term management of patients with CTD. The final aim of such investigations would be to personalize medical care according to the CTD and AAb identified.

In conclusion, choice in the type of AAb tested should be carefully evaluated according to clinical context for each patient. Importantly, to properly handle the clinical usefulness of AAb detection, clinician should also be aware of both the advantages and the limits of the methods used to test $\mathrm{AAb}$, to support the clinical evaluation, which remains the essential cornerstone for disease diagnosis and patients' management.

\section{AUTHOR CONTRIBUTIONS}

$\mathrm{KD}$ and AS designed the review. KD, LB, DG, ST, AR, FA, and AS wrote the manuscript. All the authors critically evaluated the data and approved the final version for publication.

normal blood dornors. Rev Hosp Clin Fac Med Sao Paulo (2003) 58(6):315-9. doi:10.1590/S0041-87812003000600005

8. Peene I, Meheus L, Veys EM, De Keyser F. Detection and identification of antinuclear antibodies (ANA) in a large and consecutive cohort of serum samples referred for ANA testing. Ann Rheum Dis (2001) 60(12):1131-6. doi:10.1136/ard.60.12.1131

9. Li Q-Z, Karp DR, Quan J, Branch VK, Zhou J, Lian Y, et al. Risk factors for ANA positivity in healthy persons. Arthritis Res Ther (2011) 13(2):R38. doi:10.1186/ar3271

10. Hayashi N, Koshiba M, Nishimura K, Sugiyama D, Nakamura T, Morinobu S, et al. Prevalence of disease-specific antinuclear antibodies in general population: estimates from annual physical examinations of residents of a small town over a 5-year period. Mod Rheumatol (2008) 18(2):153-60. doi:10.1007/ s10165-008-0028-1

11. Racoubian E, Zubaid RM, Shareef MA, Almawi WY. Prevalence of antinuclear antibodies in healthy Lebanese subjects, 2008-2015: a cross-sectional study involving 10,814 subjects. Rheumatol Int (2016) 36(9):1231-6. doi:10.1007/ s00296-016-3533-0

12. Roberts-Thomson PJ, Nikoloutsopoulos T, Cox S, Walker JG, Gordon TP. Antinuclear antibody testing in a regional immunopathology laboratory. ImmunolCellBiol(2003)81(5):409-12.doi:10.1046/j.1440-1711.2003.01181.x

13. Wandstrat AE, Carr-Johnson F, Branch V, Gray H, Fairhurst A-M, Reimold A, et al. Autoantibody profiling to identify individuals at risk for systemic lupus erythematosus. J Autoimmun (2006) 27(3):153-60. doi:10.1016/j. jaut.2006.09.001 
14. Nilsson B-O, Skogh T, Ernerudh J, Johansson B, Löfgren S, Wikby A, et al. Antinuclear antibodies in the oldest-old women and men. JAutoimmun (2006) 27(4):281-8. doi:10.1016/j.jaut.2006.10.002

15. Tan EM, Feltkamp TE, Smolen JS, Butcher B, Dawkins R, Fritzler MJ, et al. Range of antinuclear antibodies in "healthy" individuals. Arthritis Rheum (1997) 40(9):1601-11. doi:10.1002/art.1780400909

16. Hayashi N, Kawamoto T, Mukai M, Morinobu A, Koshiba M, Kondo S, et al. Detection of antinuclear antibodies by use of an enzyme immunoassay with nuclear HEp-2 cell extract and recombinant antigens: comparison with immunofluorescence assay in 307 patients. Clin Chem (2001) 47(9):1649-59.

17. Marin GG, Cardiel MH, Cornejo H, Viveros ME. Prevalence of antinuclear antibodies in 3 groups of healthy individuals: blood donors, hospital personnel, and relatives of patients with autoimmune diseases. J Clin Rheumatol (2009) 15(7):325-9. doi:10.1097/RHU.0b013e3181bb971b

18. Depincé-Berger AE, Moreau A, Bossy V, Genin C, Rinaudo M, Paul S. Comparison of screening dilution and automated reading for antinuclear antibody detection on HEP2 cells in the monitoring of connective tissue diseases. J Clin Lab Anal (2016) 30(5):471-8. doi:10.1002/jcla.21881

19. Bossuyt X, Cooreman S, De Baere H, Verschueren P, Westhovens R, Blockmans D, et al. Detection of antinuclear antibodies by automated indirect immunofluorescence analysis. Clin Chim Acta (2013) 415:101-6. doi:10.1016/j.cca.2012.09.021

20. Willems P, De Langhe E, Claessens J, Westhovens R, Van Hoeyveld E, Poesen $\mathrm{K}$, et al. Screening for connective tissue disease-associated antibodies by automated immunoassay. Clin Chem Lab Med (2018). doi:10.1515/ cclm-2017-0905

21. van der Pol P, Bakker-Jonges LE, Kuijpers JHSAM, Schreurs MWJ. Analytical and clinical comparison of two fully automated immunoassay systems for the detection of autoantibodies to extractable nuclear antigens. Clin Chim Acta (2018) 476:154-9. doi:10.1016/j.cca.2017.11.014

22. Robier C, Amouzadeh-Ghadikolai O, Stettin M, Reicht G. Comparison of the clinical utility of the Elia CTD Screen to indirect immunofluorescence on Hep-2 cells. Clin Chem Lab Med (2016) 54(8):1365-70. doi:10.1515/ cclm-2015-1051

23. Op De Beéck K, Vermeersch P, Verschueren P, Westhovens R, Mariën G, Blockmans D, et al. Antinuclear antibody detection by automated multiplex immunoassay in untreated patients at the time of diagnosis. Autoimmun Rev (2012) 12(2):137-43. doi:10.1016/j.autrev.2012.02.013

24. Op De Beeck K, Vermeersch P, Verschueren P, Westhovens R, Mariën G, Blockmans $\mathrm{D}$, et al. Detection of antinuclear antibodies by indirect immunofluorescence and by solid phase assay. Autoimmun Rev (2011) 10(12):801-8. doi:10.1016/j.autrev.2011.06.005

25. Meroni PL, Schur PH. ANA screening: an old test with new recommendations. Ann Rheum Dis (2010) 69(8):1420-2. doi:10.1136/ard.2009.127100

26. Ochs RL, Muro Y, Si Y, Ge H, Chan EK, Tan EM. Autoantibodies to DFS $70 \mathrm{kd} /$ transcription coactivator p75 in atopic dermatitis and other conditions. J Allergy Clin Immunol (2000) 105(6 Pt 1):1211-20. doi:10.1067/ mai.2000.107039

27. Watanabe A, Kodera M, Sugiura K, Usuda T, Tan EM, Takasaki Y, et al. AntiDFS70 antibodies in 597 healthy hospital workers. Arthritis Rheum (2004) 50(3):892-900. doi:10.1002/art.20096

28. Mahler M, Parker T, Peebles CL, Andrade LE, Swart A, Carbone Y, et al. Anti-DFS70/LEDGF antibodies are more prevalent in healthy individuals compared to patients with systemic autoimmune rheumatic diseases. J Rheumatol (2012) 39(11):2104-10. doi:10.3899/jrheum.120598

29. Shovman O, Gilburd B, Chayat C, Amital H, Langevitz P, Watad A, et al. Prevalence of anti-DFS70 antibodies in patients with and without systemic autoimmune rheumatic diseases. Clin Exp Rheumatol (2018) 36(1):121-6.

30. Lazzerini PE, Yue Y, Srivastava U, Fabris F, Capecchi PL, Bertolozzi I, et al. Arrhythmogenicity of anti-Ro/SSA antibodies in patients with torsades de pointes. Circ Arrhythm Electrophysiol (2016) 9(4):e003419. doi:10.1161/ CIRCEP.115.003419

31. Hochberg MC. Updating the American College of Rheumatology revised criteria for the classification of systemic lupus erythematosus. Arthritis Rheum (1997) 40(9):1725. doi:10.1002/art.1780400928

32. Petri M, Orbai A-M, Alarcón GS, Gordon C, Merrill JT, Fortin PR, et al. Derivation and validation of the systemic lupus international collaborating clinics classification criteria for systemic lupus erythematosus. Arthritis Rheum (2012) 64(8):2677-86. doi:10.1002/art.34473

33. Hochberg MC, Boyd RE, Ahearn JM, Arnett FC, Bias WB, Provost TT, et al. Systemic lupus erythematosus: a review of clinico-laboratory features and immunogenetic markers in 150 patients with emphasis on demographic subsets. Medicine (Baltimore) (1985) 64(5):285-95. doi:10.1097/00005792-198509000-00001

34. Koh WH, Fong KY, Boey ML, Feng PH. Systemic lupus erythematosus in 61 Oriental males. A study of clinical and laboratory manifestations. $\mathrm{Br}$ J Rheumatol (1994) 33(4):339-42. doi:10.1093/rheumatology/33.4.339

35. Ginsburg WW, Conn DL, Bunch TW, McDuffie FC. Comparison of clinical and serologic markers in systemic lupus erythematosus and overlap syndrome: a review of 247 patients. J Rheumatol (1983) 10(2):235-41.

36. Maddison PJ, Provost TT, Reichlin M. Serological findings in patients with "ANA-negative" systemic lupus erythematosus. Medicine (Baltimore) (1981) 60(2):87-94. doi:10.1097/00005792-198103000-00002

37. Boey ML, Peebles CL, Tsay G, Feng PH, Tan EM. Clinical and autoantibody correlations in Orientals with systemic lupus erythematosus. Ann Rheum Dis (1988) 47(11):918-23. doi:10.1136/ard.47.11.918

38. Ghedira I, Sakly W, Jeddi M. [Clinical and serological characteristics of systemic lupus erythematosus: 128 cases]. Pathol Biol (Paris) (2002) 50(1):18-24. doi:10.1016/S0369-8114(01)00262-0

39. Al-Maini MH, El-Ageb EM, Al-Wahaibi SS, Al-Farsi Y, Richens ER. Demographic, autoimmune, and clinical profiles of patients with systemic lupus erythematosus in Oman. Rheumatol Int (2003) 23(4):186-91. doi:10.1007/s00296-003-0303-6

40. Cortés-Hernández J, Ordi-Ros J, Labrador M, Buján S, Balada E, Segarra A, et al. Antihistone and anti-double-stranded deoxyribonucleic acid antibodies are associated with renal disease in systemic lupus erythematosus. Am J Med (2004) 116(3):165-73. doi:10.1016/j. amjmed.2003.08.034

41. Sawalha AH, Harley JB. Antinuclear autoantibodies in systemic lupus erythematosus. Curr Opin Rheumatol (2004) 16(5):534-40. doi:10.1097/01. bor.0000135452.62800.8f

42. Bentow C, Lakos G, Martis P, Wahl E, Garcia M, Viñas O, et al. International multi-center evaluation of a novel chemiluminescence assay for the detection of anti-dsDNA antibodies. Lupus (2016) 25(8):864-72. doi:10.1177/0961203316640917

43. Infantino M, Meacci F, Bentow C, Martis P, Benucci M, Afeltra A, et al. Clinical comparison of QUANTA Flash dsDNA chemiluminescent immunoassay with four current assays for the detection of anti-dsDNA autoantibodies. J Immunol Res (2015) 2015:902821. doi:10.1155/2015/902821

44. Zigon P, Lakota K, Cucnik S, Svec T, Ambrozic A, Sodin-Semrl S, et al. Comparison and evaluation of different methodologies and tests for detection of anti-dsDNA antibodies on 889 Slovenian patients' and blood donors' sera. Croat Med J (2011) 52(6):694-702. doi:10.3325/cmj.2011.52.694

45. Derksen RHWM, Bast EJEG, Strooisma T, Jacobs JWG. A comparison between the Farr radioimmunoassay and a new automated fluorescence immunoassay for the detection of antibodies against double stranded DNA in serum. Ann Rheum Dis (2002) 61(12):1099-102. doi:10.1136/ard.61.12.1099

46. Bizzaro N, Tozzoli R, Tonutti E, Piazza A, Manoni F, Ghirardello A, et al Variability between methods to determine ANA, anti-dsDNA and anti-ENA autoantibodies: a collaborative study with the biomedical industry. J Immunol Methods (1998) 219(1-2):99-107. doi:10.1016/S0022-1759(98)00140-9

47. Chan EKL, Damoiseaux J, Carballo OG, Conrad K, de Melo Cruvinel W, Francescantonio PLC, et al. Report of the first international consensus on standardized nomenclature of antinuclear antibody HEp-2 cell patterns 2014-2015. Front Immunol (2015) 6:412. doi:10.3389/fimmu.2015.00412

48. Villalta D, Bizzaro N, Corazza D, Tozzoli R, Tonutti E. Evaluation of a new automated enzyme fluoroimmunoassay using recombinant plasmid dsDNA for the detection of anti-dsDNA antibodies in SLE. J Clin Lab Anal (2002) 16(5):227-32. doi:10.1002/jcla.10045

49. Tan EM, Cohen AS, Fries JF, Masi AT, McShane DJ, Rothfield NF, et al. The 1982 revised criteria for the classification of systemic lupus erythematosus. Arthritis Rheum (1982) 25(11):1271-7. doi:10.1002/art.1780251101

50. Albani S, Massa M, Viola S, Pellegrini G, Martini A. Antibody reactivity against single stranded DNA of various species in normal children and 
in children with diffuse connective tissue diseases. Autoimmunity (1990) 8(1):77-80. doi:10.3109/08916939008998436

51. Schur PH, Sandson J. Immunologic factors and clinical activity in systemic lupus erythematosus. N Engl JMed (1968) 278(10):533-8. doi:10.1056/ NEJM196803072781004

52. Alba P, Bento L, Cuadrado MJ, Karim Y, Tungekar MF, Abbs I, et al. Anti-dsDNA, anti-Sm antibodies, and the lupus anticoagulant: significant factors associated with lupus nephritis. Ann Rheum Dis (2003) 62(6):556-60. doi:10.1136/ard.62.6.556

53. Homma M, Mimori T, Takeda Y, Akama H, Yoshida T, Ogasawara T, et al. Autoantibodies to the Sm antigen: immunological approach to clinical aspects of systemic lupus erythematosus. J Rheumatol Suppl (1987) 14(Suppl 13):188-93.

54. Yang J, Xu Z, Sui M, Han J, Sun L, Jia X, et al. Co-positivity for anti-dsDNA, -nucleosome and -histone antibodies in lupus nephritis is indicative of high serum levels and severe nephropathy. PLoS One (2015) 10(10):e0140441. doi:10.1371/journal.pone.0140441

55. Sardeto GA, Simas LM, Skare TS, Nisihara RM, UtiyamaSRR. Antinucleosome in systemic lupus erythematosus. A study in a Brazilian population. Clin Rheumatol (2012) 31(3):553-6. doi:10.1007/s10067-011-1889-9

56. Bizzaro N, Villalta D, Giavarina D, Tozzoli R. Are anti-nucleosome antibodies a better diagnostic marker than anti-dsDNA antibodies for systemic lupus erythematosus? A systematic review and a study of metanalysis. Autoimmun $\operatorname{Rev}(2012)$ 12(2):97-106. doi:10.1016/j.autrev.2012.07.002

57. Saisoong S, Eiam-Ong S, Hanvivatvong O. Correlations between antinucleosome antibodies and anti-double-stranded DNA antibodies, C3, C4, and clinical activity in lupus patients. Clin Exp Rheumatol (2006) 24(1):51-8.

58. Licht R, van Bruggen MC, Oppers-Walgreen B, Rijke TP, Berden JH. Plasma levels of nucleosomes and nucleosome-autoantibody complexes in murine lupus: effects of disease progression and lipopolyssacharide administration. Arthritis Rheum (2001) 44(6):1320-30. doi:10.1002/1529-0131(200106)44:6<1320::AID-ART224>3.0.CO;2-X

59. AmouraZ,KoutouzovS, ChabreH,CacoubP,AmouraI,MussetL,etal.Presence ofantinucleosomeautoantibodiesinarestrictedset of connectivetissuediseases: antinucleosome antibodies of the IgG3 subclass are markers of renal pathogenicity in systemic lupus erythematosus. Arthritis Rheum (2000) 43(1):76-84. doi:10.1002/1529-0131(200001)43:1<76::AID-ANR10>3.0.CO;2-I

60. Sui M, Sui M, Lin Q, Xu Z, Han X, Xie R, et al. Simultaneous positivity for anti-DNA, anti-nucleosome and anti-histone antibodies is a marker for more severe lupus nephritis. JClin Immunol (2013) 33(2):378-87. doi:10.1007/ s10875-012-9825-6

61. Wang CL, Ooi L, Wang F. Prevalence and clinical significance of antibodies to ribonucleoproteins in systemic lupus erythematosus in Malaysia. $\mathrm{Br}$ J Rheumatol (1996) 35(2):129-32. doi:10.1093/rheumatology/35.2.129

62. Benito-Garcia E, Schur PH, Lahita R; American College of Rheumatology Ad Hoc Committee on Immunologic Testing Guidelines. Guidelines for immunologic laboratory testing in the rheumatic diseases: anti-Sm and anti-RNP antibody tests. Arthritis Rheum (2004) 51(6):1030-44. doi:10.1002/art.20836

63. Flechsig A, Rose T, Barkhudarova F, Strauss R, Klotsche J, Dähnrich C, et al. What is the clinical significance of anti-Sm antibodies in systemic lupus erythematosus? A comparison with anti-dsDNA antibodies and C3. Clin Exp Rheumatol (2017) 35(4):598-606.

64. Jaekel HP, Klopsch T, Benkenstein B, Grobe N, Baldauf A, Schoessler $\mathrm{W}$, et al. Reactivities to the Sm autoantigenic complex and the synthetic SmD1-aa83-119 peptide in systemic lupus erythematosus and other autoimmune diseases. J Autoimmun (2001) 17(4):347-54. doi:10.1006/ jaut.2001.0545

65. Ahn SS, Yoo B-W, Song JJ, Park Y-B, Lee S-K, Lee S-W. Anti-Sm is associated with the early poor outcome of lupus nephritis. Int J Rheum Dis (2016) 19(9):897-902. doi:10.1111/1756-185X.12880

66. Ishizaki J, Saito K, Nawata M, Mizuno Y, Tokunaga M, Sawamukai N, et al. Low complements and high titre of anti-Sm antibody as predictors of histopathologically proven silent lupus nephritis without abnormal urinalysis in patients with systemic lupus erythematosus. Rheumatology (Oxford) (2015) 54(3):405-12. doi:10.1093/rheumatology/keu343

67. Habets WJ, Hoet MH, Sillekens PT, De Rooij DJ, Van de Putte LB, Van Venrooij WJ. Detection of autoantibodies in a quantitative immunoassay using recombinant ribonucleoprotein antigens. Clin Exp Immunol (1989) 76(2):172-7.
68. Gulko PS, Reveille JD, Koopman WJ, Burgard SL, Bartolucci AA, Alarcón GS. Survival impact of autoantibodies in systemic lupus erythematosus. J Rheumatol (1994) 21(2):224-8.

69. Kurien BT, Scofield RH. Autoantibody determination in the diagnosis of systemic lupus erythematosus. Scand J Immunol (2006) 64(3):227-35. doi:10.1111/j.1365-3083.2006.01819.x

70. Vedove CD, Del Giglio M, Schena D, Girolomoni G. Drug-induced lupus erythematosus. Arch Dermatol Res (2009) 301(1):99-105. doi:10.1007/ s00403-008-0895-5

71. Rubin RL, Waga S. Antihistone antibodies in systemic lupus erythematosus. J Rheumatol Suppl (1987) 14(Suppl 13):118-26.

72. Sun X-Y, Shi J, Han L, Su Y, Li Z-G. Anti-histones antibodies in systemic lupus erythematosus: prevalence and frequency in neuropsychiatric lupus. J Clin Lab Anal (2008) 22(4):271-7. doi:10.1002/jcla.20248

73. van Rijthoven AW, Bijlsma JWJ, Canninga-van Dijk M, Derksen RHWM, van Roon JA. Onset of systemic lupus erythematosus after conversion of infliximab to adalimumab treatment in rheumatoid arthritis with a pre-existing anti-dsDNA antibody level. Rheumatology (Oxford) (2006) 45(10):1317-9. doi:10.1093/rheumatology/kel227

74. Gisondi P, Girolomoni G. Biologic therapies in psoriasis: a new therapeutic approach. Autoimmun Rev (2007) 6(8):515-9. doi:10.1016/j. autrev.2006.12.002

75. Harley JB, Scofield RH, Reichlin M. Anti-Ro in Sjögren's syndrome and systemic lupus erythematosus. Rheum Dis Clin North Am (1992) 18(2):337-58.

76. Tikly M, Burgin S, Mohanlal P, Bellingan A, George J. Autoantibodies in black South Africans with systemic lupus erythematosus: spectrum and clinical associations. Clin Rheumatol (1996) 15(3):261-5. doi:10.1007/BF02229704

77. Riemekasten G, Hahn BH. Key autoantigens in SLE. Rheumatology (Oxford) (2005) 44(8):975-82. doi:10.1093/rheumatology/keh688

78. Kurien BT, Newland J, Paczkowski C, Moore KL, Scofield RH. Association of neutropenia in systemic lupus erythematosus (SLE) with anti-Ro and binding of an immunologically cross-reactive neutrophil membrane antigen. Clin Exp Immunol (2000) 120(1):209-17. doi:10.1046/j.1365-2249.2000.01195.x

79. Vanoni F, Lava SAG, Fossali EF, Cavalli R, Simonetti GD, Bianchetti MG, et al. Neonatal systemic lupus erythematosus syndrome: a comprehensive review. Clin Rev Allergy Immunol (2017) 53(3):469-76. doi:10.1007/ s12016-017-8653-0

80. Buyon JP, Clancy RM. Neonatal lupus: basic research and clinical perspectives. Rheum Dis Clin North Am (2005) 31(2):299-313,vii. doi:10.1016/j. rdc.2005.01.010

81. Lee LA. The clinical spectrum of neonatal lupus. Arch Dermatol Res (2009) 301(1):107-10. doi:10.1007/s00403-008-0896-4

82. Zuppa AA, Riccardi R, Frezza S, Gallini F, Luciano RMP, Alighieri G, et al. Neonatal lupus: follow-up in infants with anti-SSA/Ro antibodies and review of the literature. Autoimmun Rev (2017) 16(4):427-32. doi:10.1016/j. autrev.2017.02.010

83. Tunks RD, Clowse MEB, Miller SG, Brancazio LR, Barker PCA. Maternal autoantibody levels in congenital heart block and potential prophylaxis with antiinflammatory agents. Am J Obstet Gynecol (2013) 208(1):64.e1-7. doi:10.1016/j.ajog.2012.09.020

84. Izmirly PM, Costedoat-Chalumeau N, Pisoni CN, Khamashta MA, Kim MY, Saxena A, et al. Maternal use of hydroxychloroquine is associated with a reduced risk of recurrent anti-SSA/Ro-antibody-associated cardiac manifestations of neonatal lupus. Circulation (2012) 126(1):76-82. doi:10.1161/ CIRCULATIONAHA.111.089268

85. Rao L, Liu G, Li C, Li Y, Wang Z, Zhou Z, et al. Specificity of anti-SSB as a diagnostic marker for the classification of systemic lupus erythematosus. Exp Ther Med (2013) 5(6):1710-4. doi:10.3892/etm.2013.1051

86. Lazzerini PE, Acampa M, Guideri F, Capecchi PL, Campanella V, Morozzi $\mathrm{G}$, et al. Prolongation of the corrected QT interval in adult patients with anti-Ro/SSA-positive connective tissue diseases. Arthritis Rheum (2004) 50(4):1248-52. doi:10.1002/art.20130

87. Lazzerini PE, Capecchi PL, Acampa M, Morozzi G, Bellisai F, Bacarelli MR, et al. Anti-Ro/SSA-associated corrected QT interval prolongation in adults: the role of antibody level and specificity. Arthritis Care Res (2011) 63(10):1463-70. doi:10.1002/acr.20540

88. Lazzerini PE, Capecchi PL, Guideri F, Bellisai F, Selvi E, Acampa M, et al. Comparison of frequency of complex ventricular arrhythmias in patients 
with positive versus negative anti-Ro/SSA and connective tissue disease. Am J Cardiol (2007) 100(6):1029-34. doi:10.1016/j.amjcard.2007.04.048

89. Pickering MC, Botto M, Taylor PR, Lachmann PJ, Walport MJ. Systemic lupus erythematosus, complement deficiency, and apoptosis. Adv Immunol (2000) 76:227-324. doi:10.1016/S0065-2776(01)76021-X

90. Siegert CE, Daha MR, Swaak AJ, van der Voort EA, Breedveld FC. The relationship between serum titers of autoantibodies to $\mathrm{Clq}$ and age in the general population and in patients with systemic lupus erythematosus. Clin Immunol Immunopathol (1993) 67(3 Pt 1):204-9. doi:10.1006/clin.1993.1066

91. Trendelenburg M, Lopez-Trascasa M, Potlukova E, Moll S, Regenass S, Frémeaux-Bacchi V, et al. High prevalence of anti-C1q antibodies in biopsy-proven active lupus nephritis. Nephrol Dial Transplant (2006) 21(11):3115-21. doi:10.1093/ndt/gfl436

92. Siegert CE, Daha MR, Halma C, van der Voort EA, Breedveld FC. IgG and IgA autoantibodies to $\mathrm{Clq}$ in systemic and renal diseases. Clin Exp Rheumatol (1992) 10(1):19-23.

93. Sinico RA, Radice A, Ikehata M, Giammarresi G, Corace C, Arrigo G, et al. Anti-C1q autoantibodies in lupus nephritis: prevalence and clinical significance. Ann N Y Acad Sci (2005) 1050:193-200. doi:10.1196/annals.1313.020

94. Siegert C, Daha M, Westedt ML, van der Voort E, Breedveld F. IgG autoantibodies against $\mathrm{C} 1 \mathrm{q}$ are correlated with nephritis, hypocomplementemia, and dsDNA antibodies in systemic lupus erythematosus. J Rheumatol (1991) 18(2):230-4.

95. Gunnarsson I, Rönnelid J, Huang YH, Rogberg S, Nilsson B, Lundberg $\mathrm{I}$, et al. Association between ongoing anti-Clq antibody production in peripheral blood and proliferative nephritis in patients with active systemic lupus erythematosus. Br J Rheumatol (1997) 36(1):32-7. doi:10.1093/ rheumatology/36.1.32

96. Moroni G, Trendelenburg M, Del Papa N, Quaglini S, Raschi E, Panzeri $\mathrm{P}$, et al. Anti-C1q antibodies may help in diagnosing a renal flare in lupus nephritis. Am J Kidney Dis (2001) 37(3):490-8. doi:10.1053/ajkd.2001.22071

97. Orbai A-M, Truedsson L, Sturfelt G, Nived O, Fang H, Alarcón GS, et al. AntiC1q antibodies in systemic lupus erythematosus. Lupus (2015) 24(1):42-9. doi:10.1177/0961203314547791

98. Coremans IE, Spronk PE, Bootsma H, Daha MR, van der Voort EA, Kater $\mathrm{L}$, et al. Changes in antibodies to $\mathrm{Clq}$ predict renal relapses in systemic lupus erythematosus. Am J Kidney Dis (1995) 26(4):595-601. doi:10.1016/0272-6386(95)90595-2

99. Siegert CE, Daha MR, Tseng CM, Coremans IE, van Es LA, Breedveld FC. Predictive value of IgG autoantibodies against $\mathrm{C1q}$ for nephritis in systemic lupus erythematosus. Ann Rheum Dis (1993) 52(12):851-6. doi:10.1136/ ard.52.12.851

100. Siegert CE, Kazatchkine MD, Sjöholm A, Würzner R, Loos M, Daha MR. Autoantibodies against $\mathrm{Clq}$ : view on clinical relevance and pathogenic role. Clin Exp Immunol (1999) 116(1):4-8. doi:10.1046/j.1365-2249.1999.00867.x

101. Frémeaux-Bacchi V, Noël LH, Schifferli JA. No lupus nephritis in the absence of antiC1q autoantibodies? Nephrol Dial Transplant (2002) 17(12):2041-3. doi:10.1093/ndt/17.12.2041

102. Jachiet M, Flageul B, Deroux A, Le Quellec A, Maurier F, Cordoliani F, et al. The clinical spectrum and therapeutic management of hypocomplementemic urticarial vasculitis: data from a French nationwide study of fifty-seven patients. Arthritis Rheumatol (2015) 67(2):527-34. doi:10.1002/art.38956

103. Bonfa E, Elkon KB. Clinical and serologic associations of the antiribosomal P protein antibody. Arthritis Rheum (1986) 29(8):981-5. doi:10.1002/ art.1780290806

104. Ghirardello A, Caponi L, Franceschini F, Zampieri S, Quinzanini M, Bendo $\mathrm{R}$, et al. Diagnostic tests for antiribosomal p protein antibodies: a comparative evaluation of immunoblotting and ELISA assays. J Autoimmun (2002) 19(1-2):71-7. doi:10.1006/jaut.2002.0595

105. Borchers AT, Aoki CA, Naguwa SM, Keen CL, Shoenfeld Y, Gershwin ME. Neuropsychiatric features of systemic lupus erythematosus. Autoimmun Rev (2005) 4(6):329-44. doi:10.1016/j.autrev.2005.01.008

106. Eber T, Chapman J, Shoenfeld Y. Anti-ribosomal P-protein and its role in psychiatric manifestations of systemic lupus erythematosus: myth or reality? Lupus (2005) 14(8):571-5. doi:10.1191/0961203305lu2150rr

107. Sato T, Uchiumi T, Ozawa T, Kikuchi M, Nakano M, Kominami R, et al. Autoantibodies against ribosomal proteins found with high frequency in patients with systemic lupus erythematosus with active disease. J Rheumatol (1991) 18(11):1681-4.

108. Reichlin M. Autoantibodies to the ribosomal $\mathrm{P}$ proteins in systemic lupus erythematosus. Clin Exp Med (2006) 6(2):49-52. doi:10.1007/ s10238-006-0094-7

109. Mei Y-J, Wang P, Jiang C, Wang T, Chen L-J, Li Z-J, et al. Clinical and serological associations of anti-ribosomal P0 protein antibodies in systemic lupus erythematosus. Clin Rheumatol (2018) 37(3):703-7. doi:10.1007/ s10067-017-3886-0

110. Mok CC, Tang SSK, To CH, Petri M. Incidence and risk factors of thromboembolism in systemic lupus erythematosus: a comparison of three ethnic groups. Arthritis Rheum (2005) 52(9):2774-82. doi:10.1002/art.21224

111. Wilson WA, Gharavi AE, Koike T, Lockshin MD, Branch DW, Piette JC, et al. International consensus statement on preliminary classification criteria for definite antiphospholipid syndrome: report of an international workshop. Arthritis Rheum (1999) 42(7):1309-11. doi:10.1002/1529-0131(199907)42:7<1309::AID-ANR1>3.0.CO;2-F

112. Abreu MM, Danowski A, Wahl DG, Amigo M-C, Tektonidou M, Pacheco MS, et al. The relevance of "non-criteria" clinical manifestations of antiphospholipid syndrome: 14th international congress on antiphospholipid antibodies technical task force report on antiphospholipid syndrome clinical features. Autoimmun Rev (2015) 14(5):401-14. doi:10.1016/j.autrev.2015.01.002

113. Ruiz-Irastorza G, Egurbide M-V, Ugalde J, Aguirre C. High impact of antiphospholipid syndrome on irreversible organ damage and survival of patients with systemic lupus erythematosus. Arch Intern Med (2004) 164(1):77-82. doi:10.1001/archinte.164.1.77

114. Danowski A, de Azevedo MNL, de Souza Papi JA, Petri M. Determinants of risk for venous and arterial thrombosis in primary antiphospholipid syndrome and in antiphospholipid syndrome with systemic lupus erythematosus. J Rheumatol (2009) 36(6):1195-9. doi:10.3899/jrheum.081194

115. Lee JL, Naguwa SM, Cheema GS, Gershwin ME. Revisiting Libman-Sacks endocarditis: a historical review and update. Clin Rev Allergy Immunol (2009) 36(2-3):126-30. doi:10.1007/s12016-008-8113-y

116. Zuily S, Regnault V, Selton-Suty C, Eschwège V, Bruntz J-F, Bode-Dotto E, et al. Increased risk for heart valve disease associated with antiphospholipid antibodies in patients with systemic lupus erythematosus: meta-analysis of echocardiographic studies. Circulation (2011) 124(2):215-24. doi:10.1161/ CIRCULATIONAHA.111.028522

117. Petri M. Detection of coronary artery disease and the role of traditional risk factors in the Hopkins Lupus Cohort. Lupus (2000) 9(3):170-5. doi:10.1191/096120300678828226

118. Zuily S, Domingues V, Suty-Selton C, Eschwège V, Bertoletti L, Chaouat A, et al. Antiphospholipid antibodies can identify lupus patients at risk of pulmonary hypertension: a systematic review and meta-analysis. Autoimmun $\operatorname{Rev}(2017)$ 16(6):576-86. doi:10.1016/j.autrev.2017.04.003

119. Sciascia S, Sanna G, Murru V, Roccatello D, Khamashta MA, Bertolaccini ML. GAPSS: the global anti-phospholipid syndrome score. Rheumatology (Oxford) (2013) 52(8):1397-403. doi:10.1093/rheumatology/kes388

120. Pereira WL, Reiche EMV, Kallaur AP, Kaimen-Maciel DR. Epidemiological, clinical, and immunological characteristics of neuromyelitis optica: a review. J Neurol Sci (2015) 355(1-2):7-17. doi:10.1016/j.jns.2015.05.034

121. Dellavance A, Alvarenga RR, Rodrigues SH, Kok F, de Souza AWS, Andrade LEC. Anti-aquaporin-4 antibodies in the context of assorted immune-mediated diseases. Eur J Neurol (2012) 19(2):248-52. doi:10.1111/j.1468-1331.2011.03479.x

122. Li H, Wang Y, Xu Q, Zhang A, Zhou H, Zhao S, et al. Features of anti-aquaporin 4 antibody-seropositive Chinese patients with neuromyelitis optica spectrum optic neuritis. J Neurol (2015) 262(10):2293-304. doi:10.1007/ s00415-015-7844-y

123. Park J-H, Hwang J, Min J-H, Kim BJ, Kang E-S, Lee KH. Presence of anti-Ro/ SSA antibody may be associated with anti-aquaporin- 4 antibody positivity in neuromyelitis optica spectrum disorder. J Neurol Sci (2015) 348(1-2):132-5. doi:10.1016/j.jns.2014.11.020

124. Alexopoulos H, Kampylafka EI, Fouka P, Tatouli I, Akrivou S, Politis PK, et al. Anti-aquaporin-4 autoantibodies in systemic lupus erythematosus persist for years and induce astrocytic cytotoxicity but not CNS disease. J Neuroimmunol (2015) 289:8-11. doi:10.1016/j.jneuroim.2015.10.007 
125. Long Y, Qiu W, Lu Z, Bao J, Wu A, Wang Y, et al. Aquaporin 4 antibodies in the cerebrospinal fluid are helpful in diagnosing Chinese patients with neuromyelitis optica. Neuroimmunomodulation (2012) 19(2):96-102. doi:10.1159/000330240

126. Shiboski CH, Shiboski SC, Seror R, Criswell LA, Labetoulle M, Lietman TM, et al. 2016 American College of Rheumatology/European League Against Rheumatism classification criteria for primary Sjögren's syndrome: a consensus and data-driven methodology involving three international patient cohorts. Ann Rheum Dis (2017) 76(1):9-16. doi:10.1136/ annrheumdis-2016-210571

127. Mulli JC, Cruchaud A. Immunoreactivity to nuclear antigens in systemic lupus erythematosus with or without nephritis, and in other connective tissue diseases, with particular reference to the RNA-protein antigen. Int Arch Allergy Appl Immunol (1977) 53(3):279-89. doi:10.1159/000231763

128. Sulcebe G, Morcka K. Diagnostic and prognostic significance of different antinuclear antibodies in more than 1000 consecutive Albanian patients with rheumatic diseases. Clin Exp Rheumatol (1992) 10(3):255-61.

129. Schur PH, DeAngelis D, Jackson JM. Immunological detection of nucleic acids and antibodies to nucleic acids and nuclear antigens by counterimmunoelectrophoresis. Clin Exp Immunol (1974) 17(1):209-18.

130. Theander E, Jonsson R, Sjöström B, Brokstad K, Olsson P, Henriksson G. Prediction of Sjögren's syndrome years before diagnosis and identification of patients with early onset and severe disease course by autoantibody profiling. Arthritis Rheumatol (2015) 67(9):2427-36. doi:10.1002/art.39214

131. Skopouli FN, Dafni U, Ioannidis JP, Moutsopoulos HM. Clinical evolution, and morbidity and mortality of primary Sjögren's syndrome. Semin Arthritis Rheum (2000) 29(5):296-304. doi:10.1016/S0049-0172(00)80016-5

132. Zhao Y, Li Y, Wang L, Li X-F, Huang C-B, Wang G-C, et al. Primary Sjögren syndrome in Han Chinese: clinical and immunological characteristics of 483 patients. Medicine (Baltimore) (2015) 94(16):e667. doi:10.1097/ MD.0000000000000667

133. Fauchais AL, Martel C, Gondran G, Lambert M, Launay D, Jauberteau MO, et al. Immunological profile in primary Sjögren syndrome: clinical significance, prognosis and long-term evolution to other auto-immune disease. Autoimmun Rev (2010) 9(9):595-9. doi:10.1016/j.autrev.2010.05.004

134. Nardi N, Brito-Zerón P, Ramos-Casals M, Aguiló S, Cervera R, Ingelmo M, et al. Circulating auto-antibodies against nuclear and non-nuclear antigens in primary Sjögren's syndrome: prevalence and clinical significance in 335 patients. Clin Rheumatol (2006) 25(3):341-6. doi:10.1007/s10067-005-0059-3

135. Baer AN, McAdams DeMarco M, Shiboski SC, Lam MY, Challacombe S, Daniels TE, et al. The SSB-positive/SSA-negative antibody profile is not associated with key phenotypic features of Sjögren's syndrome. Ann Rheum Dis (2015) 74(8):1557-61. doi:10.1136/annrheumdis-2014-206683

136. Quartuccio L, Baldini C, Bartoloni E, Priori R, Carubbi F, Corazza L, et al. Anti-SSA/SSB-negative Sjögren's syndrome shows a lower prevalence of lymphoproliferative manifestations, and a lower risk of lymphoma evolution. Autoimmun Rev (2015) 14(11):1019-22. doi:10.1016/j.autrev.2015.07.002

137. Ambrosi A, Sonesson S-E, Wahren-Herlenius M. Molecular mechanisms of congenital heart block. Exp Cell Res (2014) 325(1):2-9. doi:10.1016/j. yexcr.2014.01.003

138. Brucato A, Frassi M, Franceschini F, Cimaz R, Faden D, Pisoni MP, et al. Risk of congenital complete heart block in newborns of mothers with anti-Ro/SSA antibodies detected by counterimmunoelectrophoresis: a prospective study of 100 women. Arthritis Rheum (2001) 44(8):1832-5. doi:10.1002/1529-0131(200108)44:8<1832::AID-ART320>3.0.CO;2-C

139. Salomonsson S, Sonesson S-E, Ottosson L, Muhallab S, Olsson T, Sunnerhagen $\mathrm{M}$, et al. Ro/SSA autoantibodies directly bind cardiomyocytes, disturb calcium homeostasis, and mediate congenital heart block. J Exp Med (2005) 201(1):11-7. doi:10.1084/jem.20041859

140. Bournia V-K, Vlachoyiannopoulos PG. Subgroups of Sjögren syndrome patients according to serological profiles. J Autoimmun (2012) 39(1-2):15-26. doi:10.1016/j.jaut.2012.03.001

141. Maruyama T, Saito I, Hayashi Y, Kompfner E, Fox RI, Burton DR, et al. Molecular analysis of the human autoantibody response to alpha-fodrin in Sjögren's syndrome reveals novel apoptosis-induced specificity. Am J Pathol (2004) 165(1):53-61. doi:10.1016/S0002-9440(10)63274-9

142. Qin Q, Wang H, Wang H-Z, Huang Y-L, Li H, Zhang W-W, et al. Diagnostic accuracy of anti-alpha-fodrin antibodies for primary Sjögren's syndrome. Mod Rheumatol (2014) 24(5):793-7. doi:10.3109/14397595.2013.865823
143. Hu Q, Wang D, Chen W. The accuracy of the anti- $\alpha$-fodrin antibody test for diagnosis of Sjögren's syndrome: a meta-analysis. Clin Biochem (2013) 46(15):1372-6. doi:10.1016/j.clinbiochem.2013.04.020

144. Nordmark G, Rorsman F, Rönnblom L, Cajander S, Taussig MJ, Kämpe O, et al. Autoantibodies to alpha-fodrin in primary Sjögren's syndrome and SLE detected by an in vitro transcription and translation assay. Clin Exp Rheumatol (2003) 21(1):49-56.

145. Locht H, Pelck R, Manthorpe R. Diagnostic and prognostic significance of measuring antibodies to alpha-fodrin compared to anti-Ro-52, anti-Ro-60, and anti-La in primary Sjögren's syndrome. J Rheumatol (2008) 35(5):845-9.

146. Hernández-Molina G, Nuñez-Alvarez C, Avila-Casado C, Llorente L, Hernández-Hernández $\mathrm{C}$, Calderillo $\mathrm{ML}$, et al. Usefulness of IgA anti- $\alpha-$ fodrin antibodies in combination with rheumatoid factor and/or antinuclear antibodies as substitute immunological criterion in Sjögren syndrome with negative anti-SSA/SSB antibodies. J Rheumatol (2016) 43(10):1852-7. doi:10.3899/jrheum.151315

147. van den Hoogen F, Khanna D, Fransen J, Johnson SR, Baron M, Tyndall A, et al. 2013 classification criteria for systemic sclerosis: an American College of Rheumatology/European League against Rheumatism collaborative initiative. Arthritis Rheum (2013) 65(11):2737-47. doi:10.1002/art.38098

148. Salazar GA, Assassi S, Wigley F, Hummers L, Varga J, Hinchcliff M, et al. Antinuclear antibody-negative systemic sclerosis. Semin Arthritis Rheum (2015) 44(6):680-6. doi:10.1016/j.semarthrit.2014.11.006

149. Schneeberger D, Tyndall A, Kay J, Søndergaard KH, Carreira PE, Morgiel E, et al. Systemic sclerosis without antinuclear antibodies or Raynaud's phenomenon: a multicentre study in the prospective EULAR scleroderma trials and research (EUSTAR) database. Rheumatology (Oxford) (2013) 52(3):560-7. doi:10.1093/rheumatology/kes315

150. Liaskos C, Marou E, Simopoulou T, Barmakoudi M, Efthymiou G, Scheper T, et al. Disease-related autoantibody profile in patients with systemic sclerosis. Autoimmunity (2017) 50(7):414-21. doi:10.1080/08916934.2017.1357699

151. Heijnen IAFM, Foocharoen C, Bannert B, Carreira PE, Caporali R, Smith $\mathrm{V}$, et al. Clinical significance of coexisting antitopoisomerase I and anticentromere antibodies in patients with systemic sclerosis: a EUSTAR groupbased study. Clin Exp Rheumatol (2013) 31(2 Suppl 76):96-102.

152. Mierau R, Moinzadeh P, Riemekasten G, Melchers I, Meurer M, Reichenberger F, et al. Frequency of disease-associated and other nuclear autoantibodies in patients of the German Network for Systemic Scleroderma: correlation with characteristic clinical features. Arthritis Res Ther (2011) 13(5):R172. doi:10.1186/ar3495

153. Hamaguchi Y, Hasegawa M, Fujimoto M, Matsushita T, Komura K, Kaji $\mathrm{K}$, et al. The clinical relevance of serum antinuclear antibodies in Japanese patients with systemic sclerosis. Br J Dermatol (2008) 158(3):487-95. doi:10.1111/j.1365-2133.2007.08392.x

154. Reveille JD, Solomon DH; American College of Rheumatology Ad Hoc Committee of Immunologic Testing Guidelines. Evidence-based guidelines for the use of immunologic tests: anticentromere, Scl-70, and nucleolar antibodies. Arthritis Rheum (2003) 49(3):399-412. doi:10.1002/art.11113

155. Dellavance A, Gallindo C, Soares MG, da Silva NP, Mortara RA, Andrade LEC. Redefining the Scl-70 indirect immunofluorescence pattern: autoantibodies to DNA topoisomerase I yield a specific compound immunofluorescence pattern. Rheumatology (Oxford) (2009) 48(6):632-7. doi:10.1093/ rheumatology/kep070

156. Jarzabek-Chorzelska M, Blaszczyk M, Jablonska S, Chorzelski T, Kumar V, Beutner EH. Scl 70 antibody - a specific marker of systemic sclerosis. $\mathrm{Br}$ J Dermatol (1986) 115(4):393-401. doi:10.1111/j.1365-2133.1986.tb06233.x

157. Graf SW, Hakendorf P, Lester S, Patterson K, Walker JG, Smith MD, et al. South Australian Scleroderma Register: autoantibodies as predictive biomarkers of phenotype and outcome. Int J Rheum Dis (2012) 15(1):102-9. doi:10.1111/j.1756-185X.2011.01688.x

158. Walker UA, Tyndall A, Czirják L, Denton C, Farge-Bancel D, Kowal-Bielecka $\mathrm{O}$, et al. Clinical risk assessment of organ manifestations in systemic sclerosis: a report from the EULAR Scleroderma Trials and Research group database. Ann Rheum Dis (2007) 66(6):754-63. doi:10.1136/ard.2006.062901

159. Hu PQ, Fertig N, Medsger TA, Wright TM. Correlation of serum anti-DNA topoisomerase I antibody levels with disease severity and activity in systemic sclerosis. Arthritis Rheum (2003) 48(5):1363-73. doi:10.1002/art.10977

160. Kuwana M, Kaburaki J, Mimori T, Kawakami Y, Tojo T. Longitudinal analysis of autoantibody response to topoisomerase 
I in systemic sclerosis. Arthritis Rheum (2000) 43(5):1074-84. doi:10.1002/1529-0131(200005)43:5<1074::AID-ANR18>3.0.CO;2-E

161. Kuwana M, Kaburaki J, Okano Y, Tojo T, Homma M. Clinical and prognostic associations based on serum antinuclear antibodies in Japanese patients with systemic sclerosis. Arthritis Rheum (1994) 37(1):75-83. doi:10.1002/ art.1780370111

162. Mitri GM, Lucas M, Fertig N, Steen VD, Medsger TA. A comparison between anti-Th/To- and anticentromere antibody-positive systemic sclerosis patients with limited cutaneous involvement. Arthritis Rheum (2003) 48(1):203-9. doi:10.1002/art.10760

163. Santiago M, Baron M, Hudson M, Burlingame RW, Fritzler MJ. Antibodies to RNA polymerase III in systemic sclerosis detected by ELISA. J Rheumatol (2007) 34(7):1528-34.

164. Sobanski V, Dauchet L, Lefèvre G, Lambert M, Morell-Dubois S, Sy T, et al. Prevalence of anti-RNA polymerase III antibodies in systemic sclerosis: new data from a French cohort and a systematic review and meta-analysis. Arthritis Rheumatol (2014) 66(2):407-17. doi:10.1002/art.38219

165. Phan TG, Cass A, Gillin A, Trew P, Fertig N, Sturgess A. Anti-RNA polymerase III antibodies in the diagnosis of scleroderma renal crisis sine scleroderma. J Rheumatol (1999) 26(11):2489-92.

166. Moinzadeh P, Fonseca C, Hellmich M, Shah AA, Chighizola C, Denton CP, et al. Association of anti-RNA polymerase III autoantibodies and cancer in scleroderma. Arthritis Res Ther (2014) 16(1):R53. doi:10.1186/ ar4486

167. Lazzaroni M-G, Cavazzana I, Colombo E, Dobrota R, Hernandez J, Hesselstrand R, et al. Malignancies in patients with anti-RNA polymerase III antibodies and systemic sclerosis: analysis of the EULAR scleroderma trials and research cohort and possible recommendations for screening. J Rheumatol (2017) 44(5):639-47. doi:10.3899/jrheum.160817

168. Herrick AL, Peytrignet S, Lunt M, Pan X, Hesselstrand R, Mouthon L, et al. Patterns and predictors of skin score change in early diffuse systemic sclerosis from the European Scleroderma Observational Study. Ann Rheum Dis (2018). doi:10.1136/annrheumdis-2017-211912

169. Ceribelli A, Krzyszczak ME, Li Y, Ross SJ, Chan JYF, Chan EKL, et al. Atypical clinical presentation of a subset of patients with anti-RNA polymerase III - non-scleroderma cases associated with dominant RNA polymerase I reactivity and nucleolar staining. Arthritis Res Ther (2011) 13(4):R119. doi:10.1186/ar3422

170. Shah AA, Rosen A, Hummers L, Wigley F, Casciola-Rosen L. Close temporal relationship between onset of cancer and scleroderma in patients with RNA polymerase I/III antibodies. Arthritis Rheum (2010) 62(9):2787-95. doi:10.1002/art.27549

171. Kuwana M, Kaburaki J, Mimori T, Tojo T, Homma M. Autoantibody reactive with three classes of RNA polymerases in sera from patients with systemic sclerosis. J Clin Invest (1993) 91(4):1399-404. doi:10.1172/JCI116343

172. Hamaguchi Y, Kodera M, Matsushita T, Hasegawa M, Inaba Y, Usuda T, et al. Clinical and immunologic predictors of scleroderma renal crisis in Japanese systemic sclerosis patients with anti-RNA polymerase III autoantibodies. Arthritis Rheumatol (2015) 67(4):1045-52. doi:10.1002/art.38994

173. Mahler M, Raijmakers R, Dähnrich C, Blüthner M, Fritzler MJ. Clinical evaluation of autoantibodies to a novel PM/Scl peptide antigen. Arthritis Res Ther (2005) 7(3):R704-13. doi:10.1186/ar1455

174. Hanke K, Brückner CS, Dähnrich C, Huscher D, Komorowski L, Meyer $\mathrm{W}$, et al. Antibodies against PM/Scl-75 and PM/Scl-100 are independent markers for different subsets of systemic sclerosis patients. Arthritis Res Ther (2009) 11(1):R22. doi:10.1186/ar2614

175. Wodkowski M, Hudson M, Proudman S, Walker J, Stevens W, Nikpour M, et al. Clinical correlates of monospecific anti-PM75 and anti-PM100 antibodies in a tri-nation cohort of 1574 systemic sclerosis subjects. Autoimmunity (2015) 48(8):542-51. doi:10.3109/08916934.2015.1077231

176. Rozman B, Cucnik S, Sodin-Semrl S, Czirják L, Varjú C, Distler O, et al. Prevalence and clinical associations of anti-Ku antibodies in patients with systemic sclerosis: a European EUSTAR-initiated multi-centre case-control study. Ann Rheum Dis (2008) 67(9):1282-6. doi:10.1136/ ard.2007.073981

177. Hoa S, Hudson M, Troyanov Y, Proudman S, Walker J, Stevens W, et al. Single-specificity anti-Ku antibodies in an international cohort of 2140 systemic sclerosis subjects: clinical associations. Medicine (Baltimore) (2016) 95(35):e4713. doi:10.1097/MD.0000000000004713
178. Charlton D, Laffoon M, Medsger TA, Domsic R. Long-term survival and follow-up of anti-Th/to antibody positive systemic sclerosis patients. Arthritis Rheumatol (2017) 69(Suppl 10):1-4426.

179. Sobanski V, Giovannelli J, Lynch BM, Schreiber BE, Nihtyanova SI, Harvey J, et al. Characteristics and survival of anti-U1 RNP antibody-positive patients with connective tissue disease-associated pulmonary arterial hypertension. Arthritis Rheumatol (2016) 68(2):484-93. doi:10.1002/art.39432

180. Ihn H, Yamane K, Yazawa N, Kubo M, Fujimoto M, Sato S, et al. Distribution and antigen specificity of anti-U1RNP antibodies in patients with systemic sclerosis. Clin Exp Immunol (1999) 117(2):383-7. doi:10.1046/j.1365-2249.1999.00961.x

181. Tormey VJ, Bunn CC, Denton CP, Black CM. Anti-fibrillarin antibodies in systemic sclerosis. Rheumatology (Oxford) (2001) 40(10):1157-62. doi:10.1093/rheumatology/40.10.1157

182. Aggarwal R, Lucas M, Fertig N, Oddis CV, Medsger TA. Anti-U3 RNP autoantibodies in systemic sclerosis. Arthritis Rheum (2009) 60(4):1112-8. doi:10.1002/art.24409

183. Arnett FC, Reveille JD, Goldstein R, Pollard KM, Leaird K, Smith EA, et al. Autoantibodies to fibrillarin in systemic sclerosis (scleroderma). An immunogenetic, serologic, and clinical analysis. Arthritis Rheum (1996) 39(7):1151-60. doi:10.1002/art.1780390712

184. Sharif R, Fritzler MJ, Mayes MD, Gonzalez EB, McNearney TA, Draeger $\mathrm{H}$, et al. Anti-fibrillarin antibody in African American patients with systemic sclerosis: immunogenetics, clinical features, and survival analysis. J Rheumatol (2011) 38(8):1622-30. doi:10.3899/jrheum.110071

185. Schulte-Pelkum J, Fritzler M, Mahler M. Latest update on the Ro/SS-A autoantibody system. Autoimmun Rev (2009) 8(7):632-7. doi:10.1016/j. autrev.2009.02.010

186. Fujii T, Mimori T, Akizuki M. Detection of autoantibodies to nucleolar transcription factor NOR 90/hUBF in sera of patients with rheumatic diseases, by recombinant autoantigen-based assays. Arthritis Rheum (1996) 39(8):1313-8. doi:10.1002/art.1780390808

187. Morozzi G, Bellisai F, Fineschi I, Scaccia F, Pucci G, Simpatico A, et al. Prevalence of anti-histone antibodies, their clinical significance and correlation with other autoantibodies in a cohort of Italian scleroderma patients. Auto Immun Highlights (2011) 2(1):29-33. doi:10.1007/s13317-011-0015-y

188. Hesselstrand R, Scheja A, Shen GQ, Wiik A, Akesson A. The association of antinuclear antibodies with organ involvement and survival in systemic sclerosis. Rheumatology (Oxford) (2003) 42(4):534-40. doi:10.1093/ rheumatology $/ \operatorname{keg} 170$

189. Laustriat G, Ruyssen-Witrand A, Constantin A, Barnetche T, Adoue D, Cantagrel A, et al. Anti-citrullinated peptides antibodies in systemic sclerosis: meta-analysis of frequency and meaning. Jt Bone Spine Rev Rhum (2017) 85(2):147-53. doi:10.1016/j.jbspin.2017.11.006

190. Koenig M, Fritzler MJ, Targoff IN, Troyanov Y, Senécal J-L. Heterogeneity of autoantibodies in 100 patients with autoimmune myositis: insights into clinical features and outcomes. Arthritis Res Ther (2007) 9(4):R78. doi:10.1186/ $\operatorname{ar} 2276$

191. Troyanov Y, Targoff IN, Tremblay J-L, Goulet J-R, Raymond Y, Senécal J-L. Novel classification of idiopathic inflammatory myopathies based on overlap syndrome features and autoantibodies: analysis of 100 French Canadian patients. Medicine (Baltimore) (2005) 84(4):231-49. doi:10.1097/01. md.0000173991.74008.b0

192. Hoogendijk JE, Amato AA, Lecky BR, Choy EH, Lundberg IE, Rose MR, et al. 119th ENMC international workshop: trial design in adult idiopathic inflammatory myopathies, with the exception of inclusion body myositis, 10-12 October 2003, Naarden, The Netherlands. Neuromuscul Disord (2004) 14(5):337-45. doi:10.1016/j.nmd.2004.02.006

193. Lloyd TE, Mammen AL, Amato AA, Weiss MD, Needham M, Greenberg SA. Evaluation and construction of diagnostic criteria for inclusion body myositis. Neurology (2014) 83(5):426-33. doi:10.1212/WNL.0000000000000642

194. Lega J-C, Fabien N, Reynaud Q, Durieu I, Durupt S, Dutertre M, et al. The clinical phenotype associated with myositis-specific and associated autoantibodies: a meta-analysis revisiting the so-called antisynthetase syndrome. Autoimmun Rev (2014) 13(9):883-91. doi:10.1016/j.autrev.2014.03.004

195. Connors GR, Christopher-Stine L, Oddis CV, Danoff SK. Interstitial lung disease associated with the idiopathic inflammatory myopathies: what progress has been made in the past 35 years? Chest (2010) 138(6):1464-74. doi:10.1378/chest.10-0180 
196. Yoshifuji H, Fujii T, Kobayashi S, Imura Y, Fujita Y, Kawabata D, et al. Anti-aminoacyl-tRNA synthetase antibodies in clinical course prediction of interstitial lung disease complicated with idiopathic inflammatory myopathies. Autoimmunity (2006) 39(3):233-41. doi:10.1080/08916930600622884

197. Pinal-Fernandez I, Casal-Dominguez M, Huapaya JA, Albayda J, Paik JJ, Johnson C, et al. A longitudinal cohort study of the anti-synthetase syndrome: increased severity of interstitial lung disease in black patients and patients with anti-PL7 and anti-PL12 autoantibodies. Rheumatology (Oxford) (2017) 56(6):999-1007. doi:10.1093/rheumatology/kex021

198. Hervier B, Devilliers H, Stanciu R, Meyer A, Uzunhan Y, Masseau A, et al. Hierarchical cluster and survival analyses of antisynthetase syndrome: phenotype and outcome are correlated with anti-tRNA synthetase antibody specificity. Autoimmun Rev (2012) 12(2):210-7. doi:10.1016/j.autrev.2012.06.006

199. Marie I, Josse S, Decaux O, Dominique S, Diot E, Landron C, et al. Comparison of long-term outcome between anti-Jo1- and anti-PL7/PL12 positive patients with antisynthetase syndrome. Autoimmun Rev (2012) 11(10):739-45. doi:10.1016/j.autrev.2012.01.006

200. Stone KB, Oddis CV, Fertig N, Katsumata Y, Lucas M, Vogt M, et al. Anti-Jo-1 antibody levels correlate with disease activity in idiopathic inflammatory myopathy. Arthritis Rheum (2007) 56(9):3125-31. doi:10.1002/art.22865

201. Milone M. Diagnosis and management of immune-mediated myopathies. Mayo Clin Proc (2017) 92(5):826-37. doi:10.1016/j.mayocp.2016. 12.025

202. Kassardjian CD, Lennon VA, Alfugham NB, Mahler M, Milone M. Clinical features and treatment outcomes of necrotizing autoimmune myopathy. JAMA Neurol (2015) 72(9):996-1003. doi:10.1001/jamaneurol.2015.1207

203. Arouche-Delaperche L, Allenbach Y, Amelin D, Preusse C, Mouly V, Mauhin W, et al. Pathogenic role of anti-signal recognition protein and anti-3-hydroxy-3-methylglutaryl-CoA reductase antibodies in necrotizing myopathies: myofiber atrophy and impairment of muscle regeneration in necrotizing autoimmune myopathies. Ann Neurol (2017) 81(4):538-48. doi:10.1002/ana.24902

204. Allenbach Y, Arouche-Delaperche L, Preusse C, Radbruch H, Butler-Browne G, Champtiaux N, et al. Necrosis in anti-SRP+ and anti-HMGCR+myopathies: role of autoantibodies and complement. Neurology (2018) 90(6):e507-17. doi:10.1212/WNL.0000000000004923

205. Watanabe Y, Uruha A, Suzuki S, Nakahara J, Hamanaka K, Takayama $\mathrm{K}$, et al. Clinical features and prognosis in anti-SRP and anti-HMGCR necrotising myopathy. J Neurol Neurosurg Psychiatry (2016) 87(10):1038-44. doi:10.1136/jnnp-2016-313166

206. Christopher-Stine L, Casciola-Rosen LA, Hong G, Chung T, Corse AM, Mammen AL. A novel autoantibody recognizing 200-kd and 100-kd proteins is associated with an immune-mediated necrotizing myopathy. Arthritis Rheum (2010) 62(9):2757-66. doi:10.1002/art.27572

207. Werner JL, Christopher-Stine L, Ghazarian SR, Pak KS, Kus JE, Daya NR, et al. Antibody levels correlate with creatine kinase levels and strength in anti-3-hydroxy-3-methylglutaryl-coenzyme A reductase-associated autoimmune myopathy. Arthritis Rheum (2012) 64(12):4087-93. doi:10.1002/ art. 34673

208. Ashton C, Junckerstorff R, Bundell C, Hollingsworth P, Needham M. Treatment and outcomes in necrotising autoimmune myopathy: an Australian perspective. Neuromuscul Disord (2016) 26(11):734-40. doi:10.1016/j. nmd.2016.08.013

209. Mammen AL. Statin-associated autoimmune myopathy. N Engl J Med (2016) 374(7):664-9. doi:10.1056/NEJMra1515161

210. Benveniste O, Drouot L, Jouen F, Charuel J-L, Bloch-Queyrat C, Behin A, et al. Correlation of anti-signal recognition particle autoantibody levels with creatine kinase activity in patients with necrotizing myopathy. Arthritis Rheum (2011) 63(7):1961-71. doi:10.1002/art.30344

211. Pinal-Fernandez I, Parks C, Werner JL, Albayda J, Paik J, Danoff SK, et al. Longitudinal course of disease in a large cohort of myositis patients with autoantibodies recognizing the signal recognition particle. Arthritis Care Res (2017) 69(2):263-70. doi:10.1002/acr.22920

212. Fiorentino DF, Chung LS, Christopher-Stine L, Zaba L, Li S, Mammen AL, et al. Most patients with cancer-associated dermatomyositis have antibodies to nuclear matrix protein NXP-2 or transcription intermediary factor $1 \gamma$. Arthritis Rheum (2013) 65(11):2954-62. doi:10.1002/art.38093

213. Kaji K, Fujimoto M, Hasegawa M, Kondo M, Saito Y, Komura K, et al. Identification of a novel autoantibody reactive with 155 and $140 \mathrm{kDa}$ nuclear proteins in patients with dermatomyositis: an association with malignancy. Rheumatology (Oxford) (2007) 46(1):25-8. doi:10.1093/rheumatology/ kel161

214. Trallero-Araguás E, Rodrigo-Pendás JÁ, Selva-O’Callaghan A, MartínezGómez X, Bosch X, Labrador-Horrillo M, et al. Usefulness of anti-p155 autoantibody for diagnosing cancer-associated dermatomyositis: a systematic review and meta-analysis. Arthritis Rheum (2012) 64(2):523-32. doi:10.1002/art.33379

215. Mugii N, Hasegawa M, Matsushita T, Hamaguchi Y, Oohata S, Okita H, et al. Oropharyngeal dysphagia in dermatomyositis: associations with clinical and laboratory features including autoantibodies. PLoS One (2016) 11(5):e0154746. doi:10.1371/journal.pone.0154746

216. Ceribelli A, Fredi M, Taraborelli M, Cavazzana I, Franceschini F, Quinzanini M, et al. Anti-MJ/NXP-2 autoantibody specificity in a cohort of adult Italian patients with polymyositis/dermatomyositis. Arthritis Res Ther (2012) 14(2):R97. doi:10.1186/ar3822

217. Gunawardena H, Wedderburn LR, Chinoy H, Betteridge ZE, North J, Ollier WER, et al. Autoantibodies to a 140 -kd protein in juvenile dermatomyositis are associated with calcinosis. Arthritis Rheum (2009) 60(6):1807-14. doi:10.1002/art.24547

218. Espada G, Maldonado Cocco JA, Fertig N, Oddis CV. Clinical and serologic characterization of an Argentine pediatric myositis cohort: identification of a novel autoantibody (anti-MJ) to a $142-\mathrm{kDa}$ protein. J Rheumatol (2009) 36(11):2547-51. doi:10.3899/jrheum.090461

219. Fiorentino D, Chung L, Zwerner J, Rosen A, Casciola-Rosen L. The mucocutaneous and systemic phenotype of dermatomyositis patients with antibodies to MDA5 (CADM-140): a retrospective study. J Am Acad Dermatol (2011) 65(1):25-34. doi:10.1016/j.jaad.2010.09.016

220. Chen Z, Cao M, Plana MN, Liang J, Cai H, Kuwana M, et al. Utility of anti-melanoma differentiation-associated gene 5 antibody measurement in identifying patients with dermatomyositis and a high risk for developing rapidly progressive interstitial lung disease: a review of the literature and a meta-analysis. Arthritis Care Res (2013) 65(8):1316-24. doi:10.1002/ acr. 21985

221. Zhang L, Wu G, Gao D, Liu G, Pan L, Ni L, et al. Factors associated with interstitial lung disease in patients with polymyositis and dermatomyositis: a systematic review and meta-analysis. PLoS One (2016) 11(5):e0155381. doi:10.1371/journal.pone.0155381

222. Nakashima R, Imura Y, Kobayashi S, Yukawa N, Yoshifuji H, Nojima T, et al. The RIG-I-like receptor IFIH1/MDA5 is a dermatomyositis-specific autoantigen identified by the anti-CADM-140 antibody. Rheumatology (Oxford) (2010) 49(3):433-40. doi:10.1093/rheumatology/kep375

223. Muro Y, Sugiura K, Hoshino K, Akiyama M. Disappearance of anti-MDA-5 autoantibodies in clinically amyopathic DM/interstitial lung disease during disease remission. Rheumatology (Oxford) (2012) 51(5):800-4. doi:10.1093/ rheumatology/ker408

224. Gono T, Sato S, Kawaguchi Y, Kuwana M, Hanaoka M, Katsumata Y, et al. AntiMDA5 antibody, ferritin and IL-18 are useful for the evaluation of response to treatment in interstitial lung disease with anti-MDA5 antibody-positive dermatomyositis. Rheumatology (Oxford) (2012) 51(9):1563-70. doi:10.1093/ rheumatology/kes102

225. Tarricone E, Ghirardello A, Rampudda M, Bassi N, Punzi L, Doria A. AntiSAE antibodies in autoimmune myositis: identification by unlabelled protein immunoprecipitation in an Italian patient cohort. J Immunol Methods (2012) 384(1-2):128-34. doi:10.1016/j.jim.2012.07.019

226. Betteridge ZE, Gunawardena H, Chinoy H, North J, Ollier WER, Cooper RG, et al. Clinical and human leucocyte antigen class II haplotype associations of autoantibodies to small ubiquitin-like modifier enzyme, a dermatomyositis-specific autoantigen target, in UK Caucasian adult-onset myositis. Ann Rheum Dis (2009) 68(10):1621-5. doi:10.1136/ard.2008.097162

227. Muro Y, Sugiura K, Akiyama M. Low prevalence of anti-small ubiquitin-like modifier activating enzyme antibodies in dermatomyositis patients. Autoimmunity (2013) 46(4):279-84. doi:10.3109/08916934.2012.755958

228. Kang EH, Nakashima R, Mimori T, Kim J, Lee YJ, Lee EB, et al. Myositis autoantibodies in Korean patients with inflammatory myositis: anti-140-kDa polypeptide antibody is primarily associated with rapidly progressive interstitial lung disease independent of clinically amyopathic dermatomyositis. BMC Musculoskelet Disord (2010) 11:223. doi:10.1186/1471-2474-11-223 
229. Petri MH, Satoh M, Martin-Marquez BT, Vargas-Ramírez R, Jara LJ, Saavedra MA, et al. Implications in the difference of anti-Mi-2 and -p155/140 autoantibody prevalence in two dermatomyositis cohorts from Mexico City and Guadalajara. Arthritis Res Ther (2013) 15(2):R48. doi:10.1186/ar4207

230. Schmidt K, Schmidt J. Inclusion body myositis: advancements in diagnosis, pathomechanisms, and treatment. Curr Opin Rheumatol (2017) 29(6):632-8. doi:10.1097/BOR.0000000000000436

231. Salajegheh M, Lam T, Greenberg SA. Autoantibodies against a $43 \mathrm{KDa}$ muscle protein in inclusion body myositis. PLoS One (2011) 6(5):e20266. doi:10.1371/journal.pone.0020266

232. Herbert MK, Stammen-Vogelzangs J, Verbeek MM, Rietveld A, Lundberg IE, Chinoy $\mathrm{H}$, et al. Disease specificity of autoantibodies to cytosolic $5^{\prime}$-nucleotidase $1 \mathrm{~A}$ in sporadic inclusion body myositis versus known autoimmune diseases. Ann Rheum Dis (2016) 75(4):696-701. doi:10.1136/ annrheumdis-2014-206691

233. Benveniste O, Stenzel W, Allenbach Y. Advances in serological diagnostics of inflammatory myopathies. Curr Opin Neurol (2016) 29(5):662-73. doi:10.1097/WCO.0000000000000376

234. Smolen JS, Aletaha D, McInnes IB. Rheumatoid arthritis. Lancet Lond Engl (2016) 388(10055):2023-38. doi:10.1016/S0140-6736(16)30173-8

235. Kapetanovic MC, Larsson L, Truedsson L, Sturfelt G, Saxne T, Geborek P. Predictors of infusion reactions during infliximab treatment in patients with arthritis. Arthritis Res Ther (2006) 8(4):R131. doi:10.1186/ar2020

236. Yukawa N, Fujii T, Kondo-Ishikawa S, Yoshifuji H, Kawabata D, Nojima T, et al. Correlation of antinuclear antibody and anti-double-stranded DNA antibody with clinical response to infliximab in patients with rheumatoid arthritis: a retrospective clinical study. Arthritis Res Ther (2011) 13(6):R213. doi:10.1186/ar3546

237. Othman MA, Ghazali WSW, Hamid WZWA, Wong KK, Yahya NK. Anticarbamylated protein antibodies in rheumatoid arthritis patients and their association with rheumatoid factor. Saudi Med J (2017) 38(9):934-41. doi:10.15537/smj.2017.9.20841

238. Arnett FC, Edworthy SM, Bloch DA, McShane DJ, Fries JF, Cooper NS, et al. The American Rheumatism Association 1987 revised criteria for the classification of rheumatoid arthritis. Arthritis Rheum (1988) 31(3):315-24. doi:10.1002/art.1780310302

239. Aletaha D, Neogi T, Silman AJ, Funovits J, Felson DT, Bingham CO, et al. 2010 rheumatoid arthritis classification criteria: an American College of Rheumatology/European League Against Rheumatism collaborative initiative. Arthritis Rheum (2010) 62(9):2569-81. doi:10.1002/art.27584

240. Jiang X, Frisell T, Askling J, Karlson EW, Klareskog L, Alfredsson L, et al. To what extent is the familial risk of rheumatoid arthritis explained by established rheumatoid arthritis risk factors? Arthritis Rheumatol (2015) 67(2):352-62. doi:10.1002/art.38927

241. Frisell T, Hellgren K, Alfredsson L, Raychaudhuri S, Klareskog L, Askling J. Familial aggregation of arthritis-related diseases in seropositive and seronegative rheumatoid arthritis: a register-based case-control study in Sweden. Ann Rheum Dis (2016) 75(1):183-9. doi:10.1136/annrheumdis-2014-206133

242. Franklin EC, Holman HR, Muller-Eberhard HJ, Kunkel HG. An unusual protein component of high molecular weight in the serum of certain patients with rheumatoid arthritis. JExp Med (1957) 105(5):425-38. doi:10.1084/ jem.105.5.425

243. Taylor P, Gartemann J, Hsieh J, Creeden J. A systematic review of serum biomarkers anti-cyclic citrullinated Peptide and rheumatoid factor as tests for rheumatoid arthritis. Autoimmune Dis (2011) 2011:815038. doi: $10.4061 / 2011 / 815038$

244. Jónsson T, Thorsteinsson H, Arinbjarnarson S, Thorsteinsson J, Valdimarsson H. Clinical implications of IgA rheumatoid factor subclasses. Ann Rheum Dis (1995) 54(7):578-81. doi:10.1136/ard.54.7.578

245. Tan EM, Smolen JS. Historical observations contributing insights on etiopathogenesis of rheumatoid arthritis and role of rheumatoid factor. J Exp Med (2016) 213(10):1937-50. doi:10.1084/jem.20160792

246. Farid SS, Azizi G, Mirshafiey A. Anti-citrullinated protein antibodies and their clinical utility in rheumatoid arthritis. Int J Rheum Dis (2013) 16(4):379-86. doi:10.1111/1756-185X.12129

247. Young BJ, Mallya RK, Leslie RD, Clark CJ, Hamblin TJ. Anti-keratin antibodies in rheumatoid arthritis. Br Med J (1979) 2(6182):97-9. doi:10.1136/ bmj.2.4670.97

248. Aggarwal R, Liao K, Nair R, Ringold S, Costenbader KH. Anti-citrullinated peptide antibody assays and their role in the diagnosis of rheumatoid arthritis. Arthritis Rheum (2009) 61(11):1472-83. doi:10.1002/art.24827

249. Schellekens GA, de Jong BA, van den Hoogen FH, van de Putte LB, van Venrooij WJ. Citrulline is an essential constituent of antigenic determinants recognized by rheumatoid arthritis-specific autoantibodies. J Clin Invest (1998) 101(1):273-81. doi:10.1172/JCI1316

250. Payet J, Goulvestre C, Bialé L, Avouac J, Wipff J, Job-Deslandre C, et al. Anticyclic citrullinated peptide antibodies in rheumatoid and nonrheumatoid rheumatic disorders: experience with 1162 patients. J Rheumatol (2014) 41(12):2395-402. doi:10.3899/jrheum.131375

251. Meyer O, Labarre C, Dougados M, Goupille P, Cantagrel A, Dubois A, et al. Anticitrullinated protein/peptide antibody assays in early rheumatoid arthritis for predicting five year radiographic damage. Ann Rheum Dis (2003) 62(2):120-6. doi:10.1136/ard.62.2.120

252. Syversen SW, Gaarder PI, Goll GL, Ødegård S, Haavardsholm EA, Mowinckel $P$, et al. High anti-cyclic citrullinated peptide levels and an algorithm of four variables predict radiographic progression in patients with rheumatoid arthritis: results from a 10-year longitudinal study. Ann Rheum Dis (2008) 67(2):212-7. doi:10.1136/ard.2006.068247

253. Nielen MMJ, van Schaardenburg D, Reesink HW, van de Stadt RJ, van der Horst-Bruinsma IE, de Koning MHMT, et al. Specific autoantibodies precede the symptoms of rheumatoid arthritis: a study of serial measurements in blood donors. Arthritis Rheum (2004) 50(2):380-6. doi:10.1002/art.20018

254. Salmon J-H, Perotin J-M, Morel J, Dramé M, Cantagrel A, Ziegler LE, et al. Serious infusion-related reaction after rituximab, abatacept and tocilizumab in rheumatoid arthritis: prospective registry data. Rheumatology (Oxford) (2018) 57(1):134-9. doi:10.1093/rheumatology/kex403

Conflict of Interest Statement: The authors declare that the research was conducted in the absence of any commercial or financial relationships that could be construed as a potential conflict of interest.

Copyright (c) 2018 Didier, Bolko, Giusti, Toquet, Robbins, Antonicelli and Servettaz. This is an open-access article distributed under the terms of the Creative Commons Attribution License (CC BY). The use, distribution or reproduction in other forums is permitted, provided the original author(s) and the copyright owner are credited and that the original publication in this journal is cited, in accordance with accepted academic practice. No use, distribution or reproduction is permitted which does not comply with these terms. 